\title{
8. UPPER CRETACEOUS AND CENOZOIC DEPOSITIONAL PROCESSES AND FACIES IN THE DISTAL NORTH ATLANTIC CONTINENTAL MARGIN OFF PORTUGAL, DSDP SITE 398
}

\author{
Andrés Maldonado, Instituto “Jaime Almera,” C. S. I. C., Sección de Estratigrafia, \\ Universidad de Barcelona, Spain
}

\begin{abstract}
The Upper Cretaceous and Cenozoic facies along the distal continental margin to the west of Portugal at Site 398 includes deposits of mass-gravity flows and the suspended-sediment regime. The deposits record the interplay of fine-grained sediment deposition, bottom currents, mass-gravity flows, physical oceanography, and tectonic activity. This continental margin is a passive type where deposition is characterized by a predominance of sediments which originated from differential pelagic settling processes. Deposits from suspensates grade from carbonate-rich pelagic deposits, to calcareous poor hemipelagic deposits, to carbonate-free claystones. The distribution of these three main sediment types is controlled primarily by terrigenous dilution, dissolution of calcareous components, and bottom currents. Turbiditic deposits are a ubiquitous lithofacies component of the stratigraphic section, but are more important in the lower Cenozoic than in the other stratigraphic intervals. Deposits of slumps, debris, and mud flows are well represented in some core sections, but are volumetrically less important compared to the other lithofacies.

Two facies associations, based on petrologic and structural characteristics, represent distinct natural lithologic affinities. A rhythmic association consists of alternating turbiditic and pelagic sediments. Each rhythm is composed of turbiditic and pelagic divisions, and represents deposition by a turbidity flow of local importance. Deposits of slumps, debris, and mud flows are also present in this facies association. A cyclic association consists of alternating beds of carbonate-rich pelagic deposits and carbonate-poor hemipelagic deposits. Base cut-out turbiditic sequences are irregularly distributed throughout this association. At Site 398, the lower carbonate-poor division of the cycle results from increased terrigenous dilution, associated with a minor loss of calcite through dissolution. The carbonate cycles reflect major changes of the environmental conditions associated with deposition. In contrast to the deposits of the rhythmic association, the carbonate cycles might be correlated along extensive areas of the continental margin.

The vertical stratigraphic succession at Site 398 is characterized by five facies units: (a) Unit 1 (Upper Cretaceous-Paleocene) is a pelagic facies which developed near or below the carbonate compensation depth; (b) Unit 2 (Paleocene-early Miocene) represents the rhythmic facies association and reflects a major influx of clastic sediments off the continental margin; (c) and (d) Units 3 and 4 (Miocene) are transitional facies between the rhythmic and the cyclic facies associations; and (e) Unit 5 (Pliocene-Pleistocene) is a carbonate cycle which records climatic and eustatic changes during the Quaternary.
\end{abstract}

\section{INTRODUCTION}

Site 398 is located on the lower continental rise in a small bathyal platform, at a water depth of 3910 meters on the southern margin of Vigo Seamount (Figure 1 ). The site was drilled $200 \mathrm{~km}$ off the coast of Portu- gal on the western flank of a deep trough. The trough, trending northeast-southwest across the slope and continental rise between the Iberian Peninsula and Vigo Seamount, at present precludes major access of sediment input from the continent to Site 398. This region belongs to the passive continental margin province of 


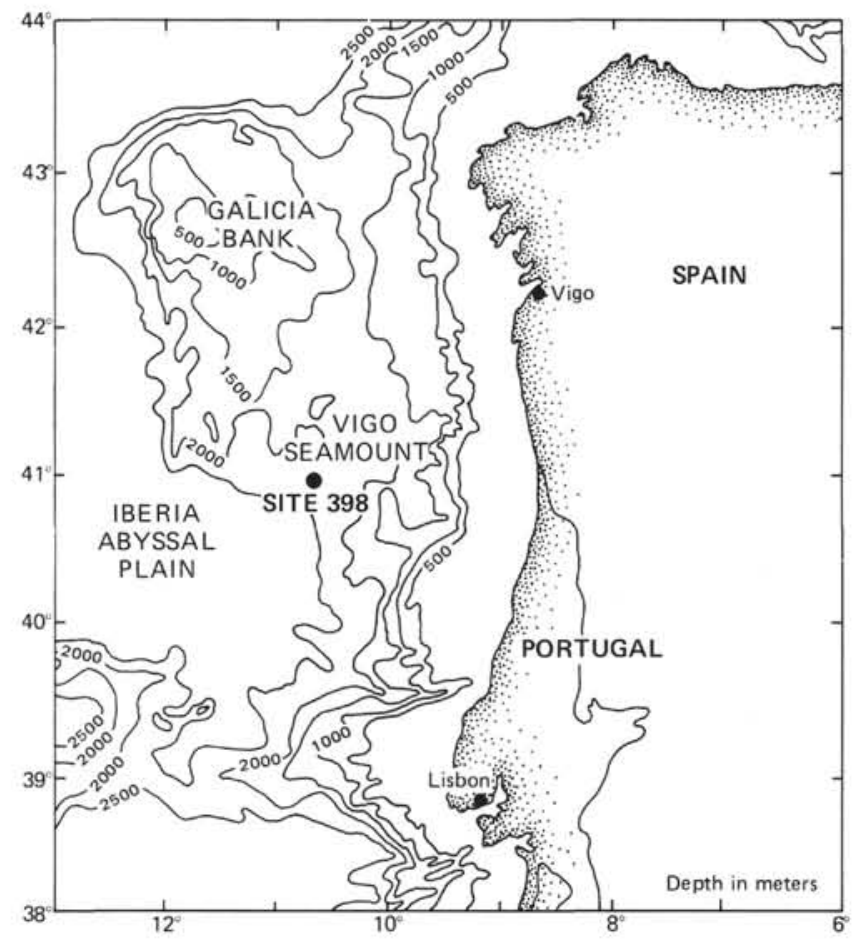

Figure 1. Map of North Atlantic continental margin off Portugal showing DSDP Site 398 (depth in $\mathrm{m}$ ).

the eastern North Atlantic and was selected for deep drilling because of the general absence of thick offshore delta deposits.

Tectonically, passive margins (except during their youthful history) are generally characterized by wide shelves, prograding slopes of moderate gradient and wide, laterally extensive continental rise wedges of deposits (cf. Inman and Nordstrom, 1971; Kelling and Stanley, 1976). The continental rise province of passive margins is mainly depositional. It has fairly smooth, or gently undulating, seaward sloping aprons, with submarine fans, fan valleys, and associated subenvironments. Continental rises (Shepard and Dill, 1966) are generally considered to have been produced by the coalescence and superimposition of adjacent fans. However, the western North Atlantic continental rise, has been ascribed largely to sedimentation and molding by deep, contour-following geostrophic currents (Heezen and Hollister, 1971; Hollister and Heezen, 1972). Finegrained hemipelagic deposits, turbidites, large gravity slide, and slumps masses also contribute to the development of the base-of-slope province (Emery et al., 1970; Kelling and Stanley, 1976; Embley, 1976).

The purpose of this study is to define, based on detailed compositional, textural, and structural analysis, the plexus of sedimentary types and facies associations that form the Cenozoic and Upper Cretaceous section. The vertical evolution of sediment types at Site 398 reflects changes in sediment transport mechanisms and processes that have occurred during the Cenozoic upbuilding at the base of slope province of a passive type continental margin.

\section{METHODS OF STUDY}

Shipboard procedures included the construction of a detailed lithologic log of sediment types and of all visible sedimentary structures. Smear slides were examined aboard ship of each major lithologic type present in the cores. Selected core sections were chosen for X-radiography (DSDP East Coast Repository), and close-up photographs were taken of the most characteristic deposits.

A total of 125 samples and 5 oriented slices of the upper Mesozoic and Cenozoic sections was taken for post-cruise petrographic analysis. The 81 samples described in detail here were selected on the basis of their relative frequency in the cores investigated, and their representativeness of each major lithology. Long slices of sediment were imbedded in resin (POLY 32032), then cut with a diamond saw and X-radiographed.

The descriptive parameters used to define the sediment types in this paper include: total carbonate content, texture, components of the sand fraction, calcareous nannofossil abundance and preservation, and sedimentary structures. The size fraction larger than $63 \mu \mathrm{m}$ was separated by wet sieving and its composition determined by counting 400 to 500 grains. Ten categories were used to summarize the composition of the sand fraction. These included: planktonic foraminifers, benthic foraminifers, foraminiferal fragments, mollusk shells, radiolarians, other invertebrates and plant debris, pyrite, mica, minerals, and other non-biogenic components. The result of the counts were recorded as the benthic to planktonic foraminifer ratio $(\mathrm{B} / \mathrm{P})$, test fragments to whole planktonic foraminifer ratio $(\mathrm{F} /$ $\mathrm{W})$, and the terrigenous to biogenic ratio (T/B); pyrite was not included in the latter group because of the uncertainty of its biogenic or terrigenous origin.

Differential solution susceptibilities of planktonic foraminifers, foraminiferal test fragmentation, benthic foraminiferal abundance, and calcium carbonate concentration have often been used to delineate changes in the intensity of carbonate dissolution (Berger, 1973; Thompson and Saito, 1974; Gardner, 1975; Thunell, $1976 \mathrm{a}, \mathrm{b})$. Multivariate analysis of deep-sea sediments from the Gulf of Mexico has demonstrated that the $\mathrm{F} / \mathrm{W}$ and $\mathrm{B} / \mathrm{P}$ ratios are probably the best indices for monitoring changes in dissolution intensity (Thunell, 1976b).

In this study, a composite foraminiferal dissolution index was determined from sample points plotted at logarithmic scales in a F/W-B/P diagram (Figure 2). On the basis of the distribution of the upper Cenozoic sediments, four main classes were distinguished on the diagram by diagonal lines $(\mathrm{F} / \mathrm{W}) \times(\mathrm{B} / \mathrm{P})$ at $10^{-2}, 10^{-1}$, $10^{\circ}$, and $10^{1}$. Class $A$ correspond to the best preserved samples; classes $B, C$, and $D$ are listed in order of increased dissolution. Each class was subdivided into two subclasses $\left(A_{1}\right.$ to $D_{1}$ and $A_{2}$ to $\left.D_{2}\right)$ by a perpendicular line to the diagonal lines, which separates the plotted sediment into two main groups (Figure 2A). Sediments without foraminiferal components or falling beyond 

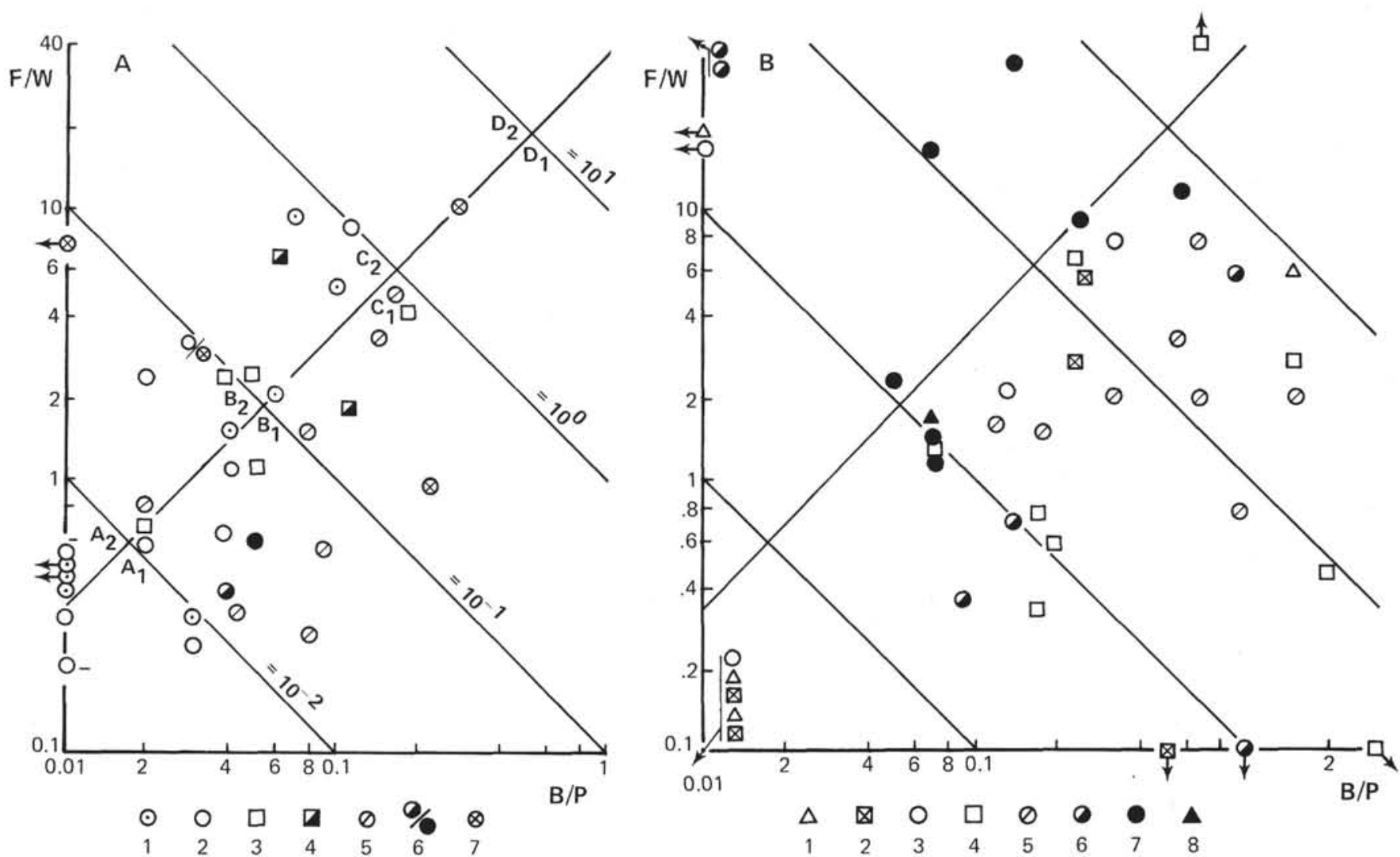

Figure 2. Plots of compositional parameters of the foraminiferal assemblages in the sand $>63 \mu m)$ fraction. The benthic to planktonic foraminifers $(B / P)$ ratio and the test fragments to whole planktonic foraminifers $(T / W)$ ratio are plotted logarithmically for each sample. Diagram used to define a composite dissolution index. On the basis of samples distribution in diagram A (Cores 398-2 to 398D-8), four main classes are distinguished. Class A corresponds to the best preserved samples; Classes $B, C$, and $D$ are listed in order of increased dissolution. Samples without foraminifers or plotted towards the edges of the diagram are attributed to another class $(O)$. Lines $(F / W) \cdot(B / P)=10^{-2},=10^{-1},=10^{0}$, and $=10^{1}$ separate the four classes. A line perpendicular to the above lines, which separate the plotted sediments in diagram $A$ into two main groups, subdivide each class into two subclasses (A1 to D1, and A2 to D2). (A) Cores 398-2 to 398D-8: 1 and 2, pelagic deposits; 3 and 4, hemipelagic deposits; 5, turbiditic mud; 6, turbiditic silt and sand; 7, bottom-winnowed deposits. (B) Cores 398D-9 to 398D-56; 1, 2, 3, and 4, deposits of differential pelagic settling; 5, turbiditic mud; 6, turbiditic silt; 7 , turbiditic sand; 8 , slump deposits.

the above subclasses are ascribed to another subclass $(0)$.

The silt and clay fraction was investigated with an SEM. A smear slide of the total sediment was placed on a metal specimen plug and coated with platinum or gold. The sample was systematically examined with a Cambridge Instrument Stereoscan at low magnification $(100 \times$ to $500 \times)$ for rapid inventory of the fossil and detrital assemblages, and at high magnification $(2000 \times$ to $5000 \times)$ for analysis of the calcareous nannofossil assemblages. Calcareous nannoplankton dissolution was recorded on a preservation scale from -1 to -5 as described by Blechschmidt (1976). The best-preserved samples found at Site 398 were classified as Index 0 . Abundance estimates of nannofossils were tabulated as the number of nannofossil specimens per field of view in a SEM photograph at a magnification of $2000 \times$.

Sediment texture was analyzed using sedimentation and hydrometer measurements for the fine fractions and mechanical sieving for particles larger than $40 \mu \mathrm{m}$. A PL/I computer program was used for the calculation of the grain-size distribution and statistical parameters (Maldonado et al., 1973).

The data used to construct the figures in this paper are summarized in Tables 1 and 2, and listed in Appendices $\mathrm{A}, \mathrm{B}$, and $\mathrm{C}$.

\section{MAJOR SEDIMENT TYPES AND DEPOSITIONAL PROCESSES}

Shipboard core examination and X-ray radiography analysis of minor sedimentary structures, coupled with the petrographic analysis of sediment types, show that the main sedimentary processes during the Cenozoic at Site 398 consist of a combination of differential pelagic settling, bottom currents, turbidity currents, and other mass gravity processes (cf. Bouma, 1964, 1975; Huang and Goodell, 1970; Rupke and Stanley, 1974; Maldonado and Stanley, 1976a, b). Sediments within these 
TABLE 1

Compositional and Textural Characteristics of Sediment Types, Cores 398-2 to 398D-8

\begin{tabular}{|c|c|c|c|c|c|c|c|c|c|c|c|c|c|}
\hline \multirow{2}{*}{$\begin{array}{c}\text { Sediment } \\
\text { Type }\end{array}$} & \multicolumn{4}{|c|}{ Per Cent } & \multicolumn{2}{|c|}{ Sand Fraction } & \multicolumn{2}{|c|}{ Nannofossils } & \multicolumn{5}{|c|}{ Texture } \\
\hline & $\mathrm{CaCO}_{3}$ & Sand & Silt & Clay & Preserv. & $\mathrm{T} / \mathrm{B}$ & $\begin{array}{c}\text { Preserv. } \\
(-)\end{array}$ & Abund. & Type & $\mathrm{C}(\mu \mathrm{m})$ & $\mathrm{M}(\mu \mathrm{m})$ & $\sigma \rho$ & $\alpha \rho$ \\
\hline 1 & $\geqslant 70$ & $4-7$ & $20-45$ & $55-70$ & $A_{2}-C_{2}$ & $\begin{array}{l}<0.01-0.05 \\
\text { (1) }\end{array}$ & $0-2$ & $>60(45)$ & Silty clay & $40-300$ & $2-4$ & $1.2-2.3$ & $-0.1-0.4$ \\
\hline 2 & $40-70$ & $<8$ & $17-48$ & $49-80$ & $\mathrm{~A}-\mathrm{B}\left(\mathrm{C}_{2}\right)$ & $<0.01-0.2$ & $\begin{array}{l}1-2 \\
(0)\end{array}$ & $18->60$ & Silty clay & $40-300$ & $1.4-4$ & $1.7-2.8$ & $-0.2-0.2$ \\
\hline 3 & $17-50$ & $<3$ & $30-40$ & $55-67$ & $\mathrm{~B}-\mathrm{C}$ & $0.05-2.0$ & $1-2$ & $7-22$ & Silty clay & $70-100$ & $1.4-2.8$ & $1.7->4$ & $0.14-0.5$ \\
\hline 4 & $4-15$ & $<5$ & $20-55$ & $40-75$ & C & 1.4 & $1-3$ & $<5$ & $\begin{array}{l}\text { Silty clay to } \\
\text { clayey silt }\end{array}$ & $35-80$ & $1-7$ & $2-3$ & $0.05-0.25$ \\
\hline 5 & $20-70$ & $<4$ & $32-40$ & $54-70$ & $\mathrm{~B}-\mathrm{C}_{1}$ & $0.01-4$ & $2(1)$ & $20-35$ & Silty clay & $\begin{array}{l}38-95 \\
(270)\end{array}$ & $1.6-3.2$ & $\begin{array}{l}1.5-2 \\
(4.5)\end{array}$ & $-0.21-0.45$ \\
\hline 6 & $8-40$ & $6->11$ & $51->62$ & $<27-43$ & $\mathrm{~B}_{1}$ & $0.5->13$ & $1-2$ & $12-30$ & $\begin{array}{l}\text { Clayey silt to } \\
\text { sandy silt }\end{array}$ & $80->130$ & $5->11$ & $3-3.5$ & $0.3-0.5$ \\
\hline 7 & $45-80$ & $\begin{array}{l}<7 \\
(38)\end{array}$ & $\begin{array}{l}38-48 \\
(46)\end{array}$ & $\begin{array}{l}45-65 \\
(15)\end{array}$ & $B-C-D$ & $\begin{array}{l}0.03-0.1 \\
(3.5)\end{array}$ & $0-2$ & $15-28$ & $\begin{array}{l}\text { Silty clay, } \\
\text { clayey silt, } \\
\text { sandy silt }\end{array}$ & $38-90$ & $\begin{array}{l}2-4.5 \\
(42)\end{array}$ & $1.4-2.2$ & $\begin{array}{l}0-0.4 \\
(0.6)\end{array}$ \\
\hline
\end{tabular}

Note:

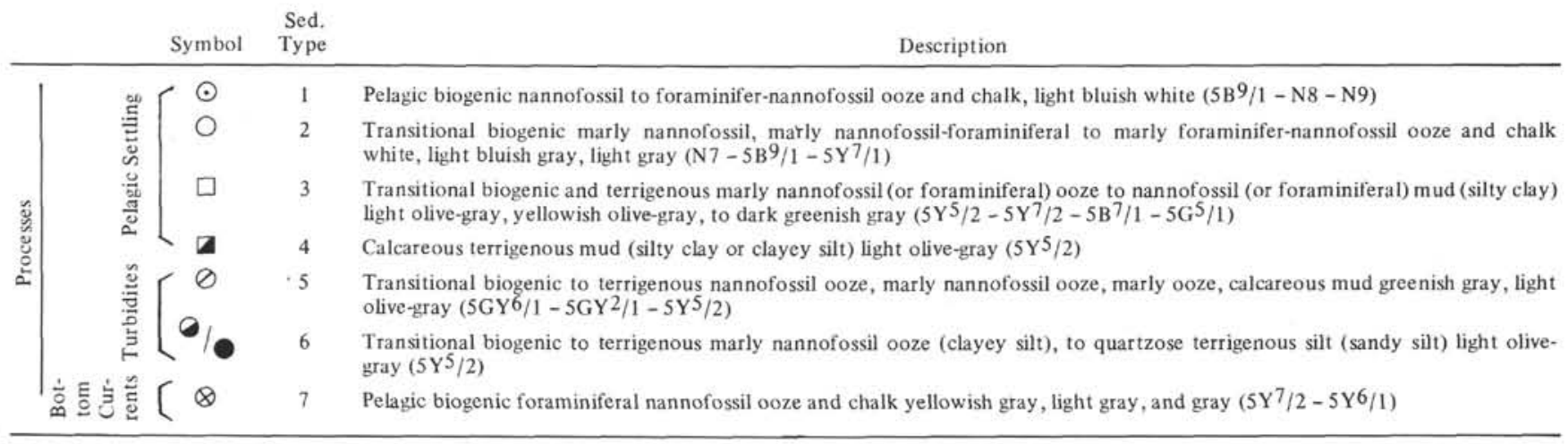

TABLE 2

Compositional and Textural Characteristics of Sediment Types, Cores 398D-9 to 398D-56

\begin{tabular}{|c|c|c|c|c|c|c|c|c|c|c|c|c|c|}
\hline \multirow{2}{*}{$\begin{array}{l}\text { Sediment } \\
\text { Type }\end{array}$} & \multicolumn{4}{|c|}{ Per Cent } & \multicolumn{2}{|c|}{ Sand Fraction } & \multicolumn{2}{|c|}{ Nannofossils } & \multicolumn{5}{|c|}{ Texture } \\
\hline & $\mathrm{CaCO}_{3}$ & Sand & Silt & Clay & Preserv. & $\mathrm{T} / \mathrm{B}$ & $\begin{array}{c}\text { Preserv. } \\
(-)\end{array}$ & Abund. & Type & $\mathrm{C}(\mu \mathrm{m})$ & $\mathrm{M}(\mu \mathrm{m})$ & $\sigma \rho$ & $\alpha \rho$ \\
\hline 1 & $16-22$ & $<2.6$ & $20-48$ & $50-85$ & $0-C_{2}-D_{1}$ & $0.25-11$ & $3-5$ & $<4$ & Silty clay & $38-100$ & $0.02-4$ & $>2.4$ & $0.2-0.4$ \\
\hline 2 & $<15$ & $<1.1$ & $21-34$ & $66-78$ & $0-C_{1}^{2}-D_{1}^{1}$ & $0.6->40$ & $4-5$ & $<1$ & Silty clay & $35-65$ & $0.1-1.3$ & $>4.5$ & $0.3-0.45$ \\
\hline 3 & $54-69$ & $<2$ & $42-45$ & $53-57$ & $C-D_{1}(0)$ & $0.5-10$ & $1-2$ & $14-35$ & Silty clay & $38-65$ & $3-4$ & $1.3-1.7$ & $<-0.5-0.1$ \\
\hline 4 & $14-56$ & $<2(6)$ & $15-48$ & $51-85$ & $\mathrm{~B}_{1}-\mathrm{C}_{1}-\mathrm{D}_{1}(0)$ & $0.5-5$ & $2-4$ & $2-6(32)$ & Silty clay & $\begin{array}{l}30-70 \\
(240)\end{array}$ & $0.4-4$ & $>2.1$ & $0.05->0.5$ \\
\hline 5 & $29-74$ & $<2$ & $25-47$ & $52-73$ & $C_{1}-D_{1}$ & $0.3-22$ & $2-3$ & $2-13$ & Silty clay & $36-85$ & $0.9-5$ & $1.6-3.8$ & $0.05-0.45$ \\
\hline 6 & $14-26$ & $3-14$ & $40-70$ & $17-57$ & $\mathrm{~B}_{1}-\mathrm{C}_{1}-\mathrm{D}_{1}(0)$ & $0.5-30$ & $2-4$ & $<10$ & Clayey silt & $70-140$ & $3-8$ & $1.8-3.1$ & $\begin{array}{l}0-0.13 \\
(<-0.5)\end{array}$ \\
\hline 7 & $23-68$ & $13-65$ & $18-48$ & $2-50$ & $B-C-D$ & $0.13-1.1$ & $1-3$ & $2-19$ & $\begin{array}{l}\text { Clayey silt } \\
\text { Clayey sand } \\
\text { Silty sand }\end{array}$ & $95-220$ & $4-165$ & $1.4->4.5$ & $-0.15->0.5$ \\
\hline 8 & 72 & 1 & 53 & 46 & $\mathrm{C}_{1}$ & 0.5 & 2 & 28 & Clayey silt & 71 & 4 & 1.4 & 0.15 \\
\hline
\end{tabular}

Note:

\begin{tabular}{|c|c|c|c|c|}
\hline & & Symbol & $\begin{array}{l}\text { Sed. } \\
\text { Type }\end{array}$ & Description \\
\hline & & $\triangle$ & 1 & Calcareous mudstone greenish gray, dusky grayish green $\left(5 G^{7} / 1-5 G Y^{6} / 1-10 G Y^{5} / 2\right)$ \\
\hline & $\mid \frac{20}{2} \stackrel{2}{2}$ & $\bigotimes$ & 2 & Quartzose mudstone to claystone yellowish red and reddish yellow $\left(5 \mathrm{YR}^{5} / 6-10 \mathrm{YR}^{7} / 3\right)$ \\
\hline & ڤั & $\bigcirc$ & 3 & Transitional biogenic marly nannofossil (foraminiferal) chalk white bluish (N9 $-5 \mathrm{~B} 9 / 1$ ) \\
\hline & & $\square$ & 4 & $\begin{array}{l}\text { Zeolitic mudstone, calcareous mudstone to marly nannofossil (foraminiferal) chalk olive-gray, pale brown, brown }\left(5 Y^{5} / 1-10 \mathrm{YR}^{5} / 3\right. \\
\left.-5 \mathrm{YR}^{4} / 4\right)\end{array}$ \\
\hline \& & 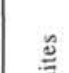 & $\varnothing$ & 5 & $\begin{array}{l}\text { Nanno (foram) chalk, marly nannofossil chalk, siliceous nannofossil (foraminiferal) mudstone greenish gray, olive-gray, dusky yellow } \\
\text { green }\left(5 G^{6} / 1-5 Y^{5} / 1-5 G Y^{5} / 2\right)\end{array}$ \\
\hline & 总 & ( & 6 & $\begin{array}{l}\text { Siliceous nannofossil mudstone, to siliceous calcareous quartz siltstone greenish gray, dusky yellow green, light bluish gray (5GY } 6 / 1 \text { - } \\
\left.10 Y^{5} / 2-5 G^{7} / 1-5 B^{7} / 1\right)\end{array}$ \\
\hline & & & 7 & $\begin{array}{l}\text { Siliceous-calcareous-quartz silty sandstone, calcareous silty sandstone, siliceous foraminiferal-nannofossil sandy mudstone, bluish } \\
\text { white greenish gray, pale olive }\left(5 \mathrm{~B}^{9} / 1-5 \mathrm{G} \mathrm{Y}^{5} / 1-5 \mathrm{G}^{6} / 1-10 \mathrm{Y}^{5} / 2\right)\end{array}$ \\
\hline & 蒠 & $\Delta$ & 8 & Nannofossil-foraminiferal chalk multicolored greenish gray, light bluish gray, pale olive $\left(5 G 6 / 1-5 G^{6} 6 / 1-5 B^{7} / 1-5 Y^{7} / 2\right)$ \\
\hline
\end{tabular}


four genetic types, described below, are defined on the basis of compositional and textural parameters.

The upper Cenozoic section is characterized by finegrained sediments (usually silty-clay and less frequently clayey-silt) consisting generally of thick to very thick carbonate-rich $\left(>50 \% \mathrm{CaCO}_{3}\right)$ pelagic biogenic ooze and chalk beds that alternate with thick carbonate-poor (less than $50 \%$ of total carbonate content) terrigenous and transitional biogenic sediment beds. The lower Cenozoic and Upper Cretaceous section (below Core 398D-8) is composed of relatively abundant thin terrigenous or calcareous silty and sandy beds, medium to thick mudstone beds (with less than $50 \%$ total carbonate content), and subordinate amounts of pebbly mudstone and slump deposits.

Figures 2 through 8 are ternary and bivariant plots of the studied samples, summarizing the variations of composition and texture. Samples from Cores 398-2 to 398D-8 of the upper Cenozoic are represented in the A diagrams of Figures 2 through 8 . The B diagrams contain samples from Core 398D-9 to the first section of Core 398D-56, i.e., lower Cenozoic and Upper Cretaceous.

\section{Sediments From Differential Pelagic Settling \\ Upper Cenozoic}

Sediments attributed to differential pelagic settling are the most abundant deposits of the upper Cenozoic section. These are structurally momogeneous deposits and bioturbation is the only type of sedimentary structure commonly observed. Light specks dispersed in the fine matrix, produced by large numbers of biogenic tests (mostly foraminifers and radiolarians), are also seen in the X-radiographs.

The four sediment types recognized in this group form the following continuous spectrum grading: from (1) light-colored pelagic biogenic nannofossil ooze and

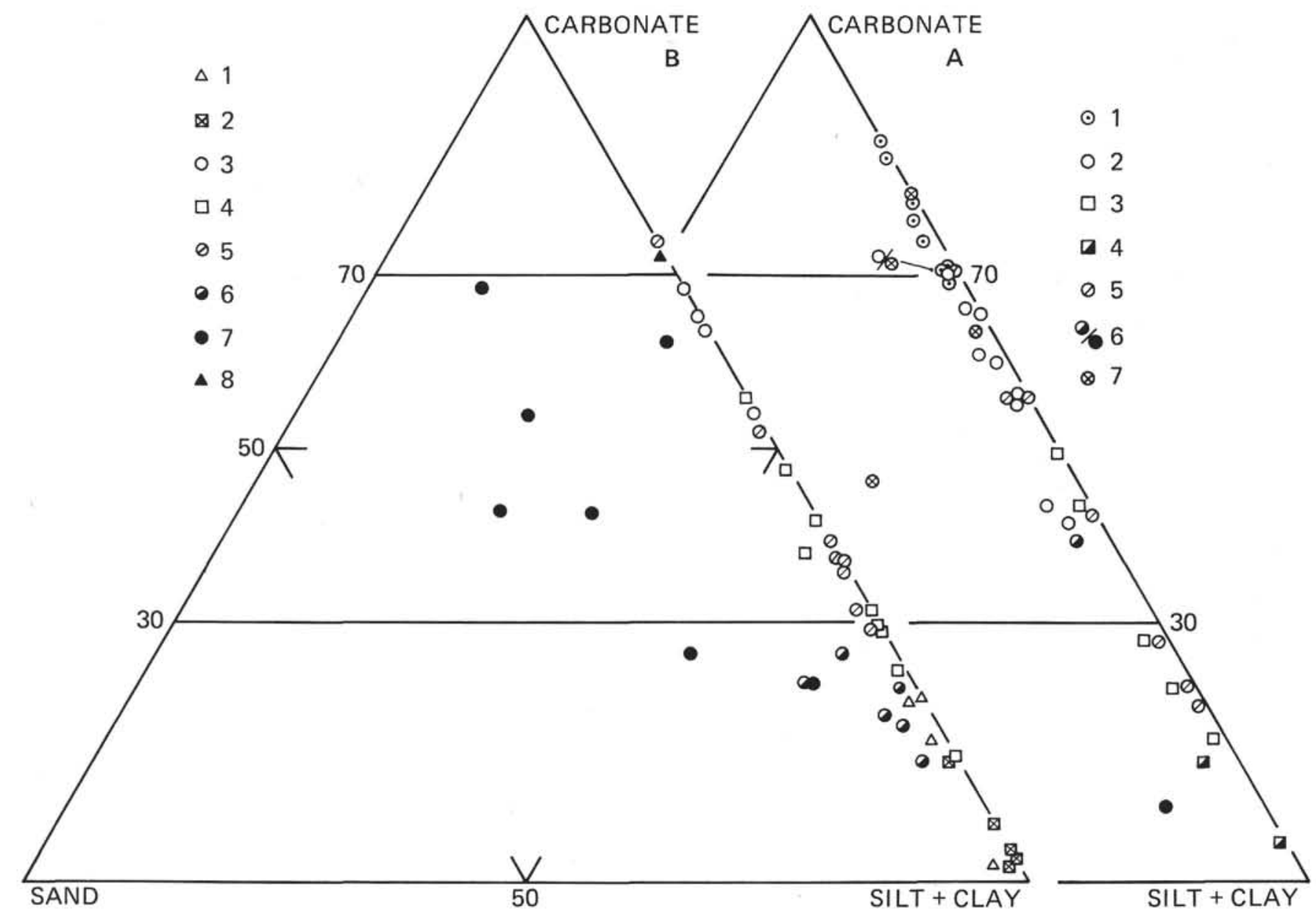

Figure 3. Compositional plots of selected bulk samples from Site 398. (A) Cores 398-2 to 398D-8: 1 and 2, pelagic deposits; 3 and 4, hemipelagic deposits; 5, turbiditic mud; 6, turbiditic silt and sand; 7, bottom-winnowed deposits. (B) Cores 398D-9 to 398D-56: 1, 2, 3, and 4, deposits of differential pelagic settling; 5, turbiditic mud; 6 , turbiditic silt; 7 , turbiditic sand; 8, slump deposits. 


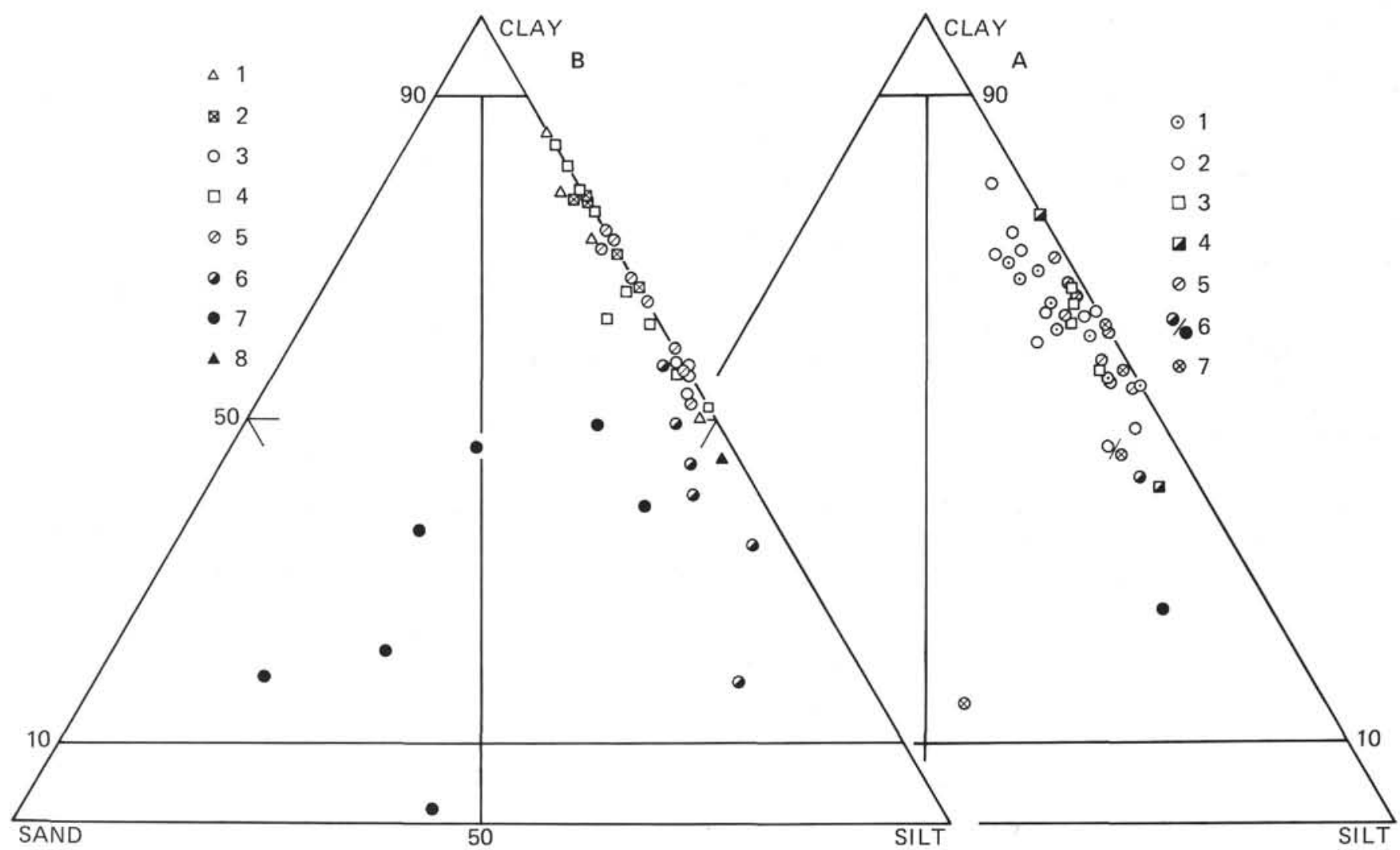

Figure 4. Textural plots of selected samples from Site 398. (A) Cores 398-2 to 398D-8: 1 and 2, pelagic deposits; 3 and 4, hemipelagic deposits; 5, turbiditic mud; 6, turbiditic silt and sand; 7, bottom-winnowed deposits. (B) Cores 398D-9 to 398D-56: 1, 2, 3, and 4, deposits of differential pelagic settling; 5, turbiditic mud; 6, turbiditic silt; 7, turbiditic sand; 8, slump deposits.

chalk, to (2) transitional biogenic ooze and chalk, to (3) transitional biogenic and terrigenous ooze and mud, to (4) olive-gray calcareous terrigenous mud and mudstone (Types 1 to 4 in Table 1 , Figures $3 \mathrm{~A}$ and 4A). Total carbonate content in these sediment types varies from between more than 70 per cent for Type 1 to less than 15 per cent for Type 4 . Types 1 and 2 are considered to be pelagic deposits, although they contain some terrigenous material; Types 3 and 4 are hemipelagic deposits (Gary et al., 1973).

Foraminiferal assemblages of the pelagic biogenic sediments are usually well preserved (dissolution Index $A_{2}$ ), but some samples show the effect of dissolution (Index $C_{2}$, Figure $2 \mathrm{~A}$ ). The assemblages in the calcareous terrigenous mud have a slightly poorer preservation (dissolution Index $C$ ). The terrigenous to biogenic ratios of the sand fraction increase in value from the biogenic to the terrigenous sediment types. No correlation is observed between total carbonate of the bulk sample and terrigenous content of the sand fraction (Table 1, Figure 5A).

The same patterns are observed in the calcareous nannofossil assemblages, which generally show higher abundance and better preservation in the pelagic biogenic sediments than in the calcareous terrigenous sediments (Table 1; Figure 6A; Plate 1, Figures 4, 7, 8, and 9).
Pelagic sediments are characterized by a rather limited range of median size (cumulative 50\% diameter = M) values, generally ranging between 1 and $4 \mu \mathrm{m}$, and a greater variation of centilo (cumulative $1 \%$ diameter $=\mathrm{C}$ ) values ( 30 to $300 \mu \mathrm{m}$ ) as result of the planktonic foraminifer content. These sediments are scattered in a broad pattern parallel to $\mathrm{C}$ (Figure 7A) in the CM diagram (Passega, 1957; Passega and Byramjee, 1969). They are interpreted as being deposits from "pelagic" (cf. Passega, 1957) and the finest uniform suspensions. Calcareous terrigenous sediments of this group are mixtures of varying amounts of detrital lutite and biogenic tests; the highly variable amounts of detrital particles in this sediment type are reflected by poorer sorting and generally greater positive skewness than for the biogenic sediments (Table 1, Figure 8A).

\section{Lower Cenozoic and Upper Cretaceous}

Lower Cenozoic and Upper Cretaceous sediments attributed to pelagic settling are subdivided into four types: (1) calcareous mudstone, (2) quartzose mudstone to claystone, (3) transitional biogenic marly chalk, and (4) zeolitic mudstone (Types 1 to 4 in Table 2). Total carbonate content varies between 54 and 69 per cent in Type 3 to less than 15 per cent in Type 2. Pelagic biogenic and calcareous terrigenous sediments (Types 1 and 4 in Table 1) are absent in this facies. 
DEPOSITIONAL PROCESSES

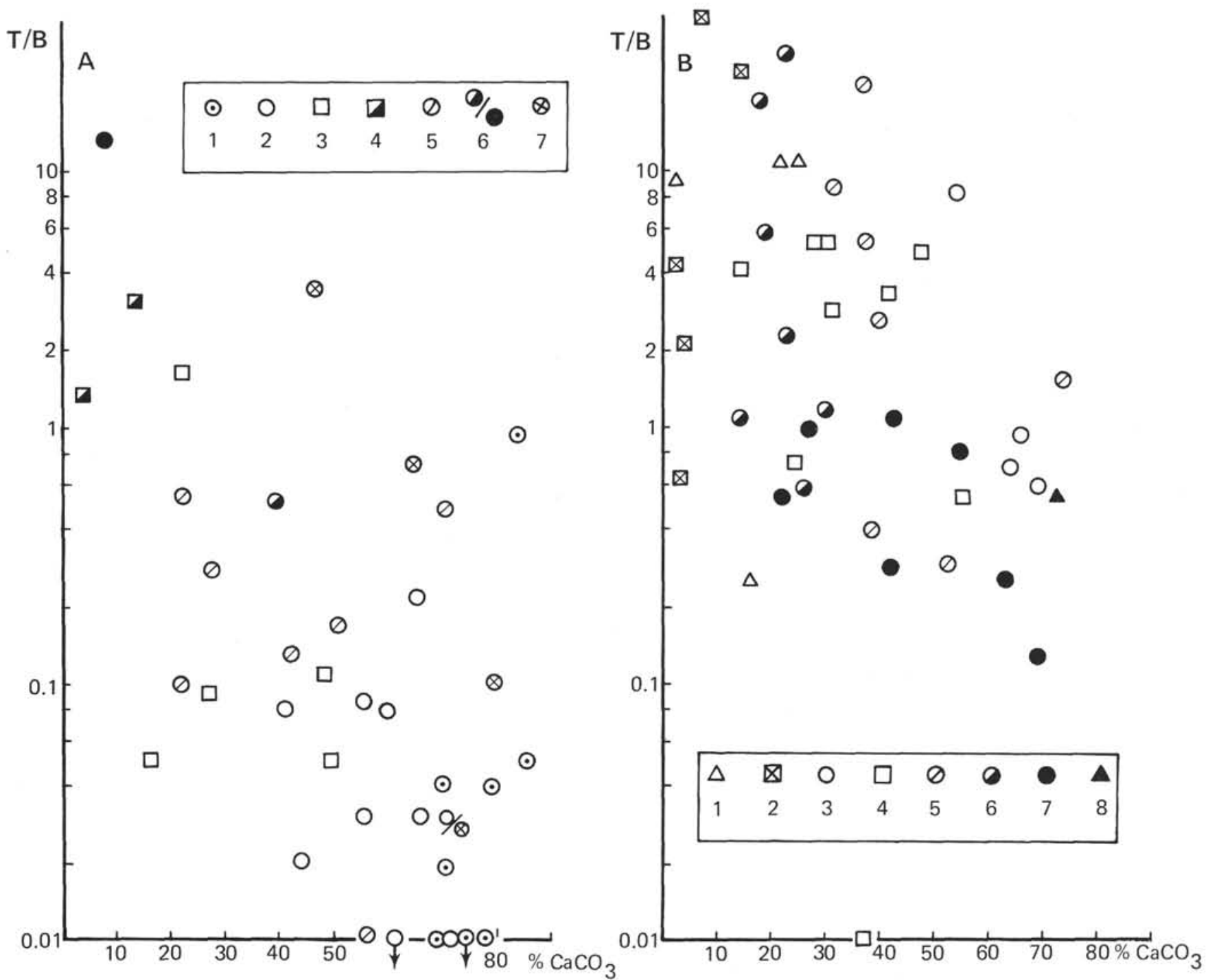

Figure 5. Compositional plots showing per cent of total carbonate (\% $\left.\mathrm{CaCO}_{3}\right)$ in the bulk sediment and the terrigenous to biogenic $(T / B)$ ratio in the sand $(>63 \mu \mathrm{m})$ fraction. Sediment types characterized by calcareous dissolution or terrigenous dilution tend to be distributed toward the upper left corner of the diagram. (A) Cores 398-2 to 398D-8: 1 and 2, pelagic deposits; 3 and 4, hemipelagic deposits; 5, turbiditic mud; 6, turbiditic silt and sand; 7, bottom-winnowed deposits. (B) Cores 398D-9 to 398D-56: 1, 2, 3, and 4, deposits of differential pelagic settling; 5, turbiditic mud; 6, turbiditic silt; 7, turbiditic sand; 8 , slump deposits.

The mudstone and claystone Type 2 , defined by the abundance of quartz and generally high T/B ratio, extends from Core 398D-32 to the top section of Core 398D-56. Greenish gray calcareous mudstone of this group (Type 1; Plate 2, Figure 8) is a diagenetic derivative of the pale-brown zeolitic mudstone (Type 4; Plate 2, Figure 9). The former results from post-depositional bacterial and burrowing activity, as well as dissolution of the calcareous components, due to the development of temporary reducing conditions in the interstitial waters (see Lithostratigraphy Chapter, this volume). These conditions were created by the superimposition of overlying, more organic-rich turbiditic deposits which may have led to an increase of bacterial and burrowing activity.
Foraminiferal dissolution indices are generally high and calcareous nannoplankton assemblages show variable effects of dissolution (Table 2; Figures 2B and 6B; Plate 2, Figures 7, 8, 9, 10, 12, and 13). The general pattern observed is better preservation and abundance for sediment types with higher average total carbonate content. Moreover, carbonate-rich sediments display coarser grain size and lower terrigenous ratios than carbonate-poor sediments (Figures 3B and 5B).

Pelagic sediments of the lower Cenozoic interval are plotted as a pattern parallel to $\mathrm{M}$ in the $\mathrm{CM}$ diagram, at about $\mathrm{C}=40 \mu \mathrm{m}$ (Figure 7B). These sediments are interpreted as deposits of pelagic suspensions (cf. Passega and Byramjee, 1969). The transitional biogenic sediment type has negative or slightly positive skew- 

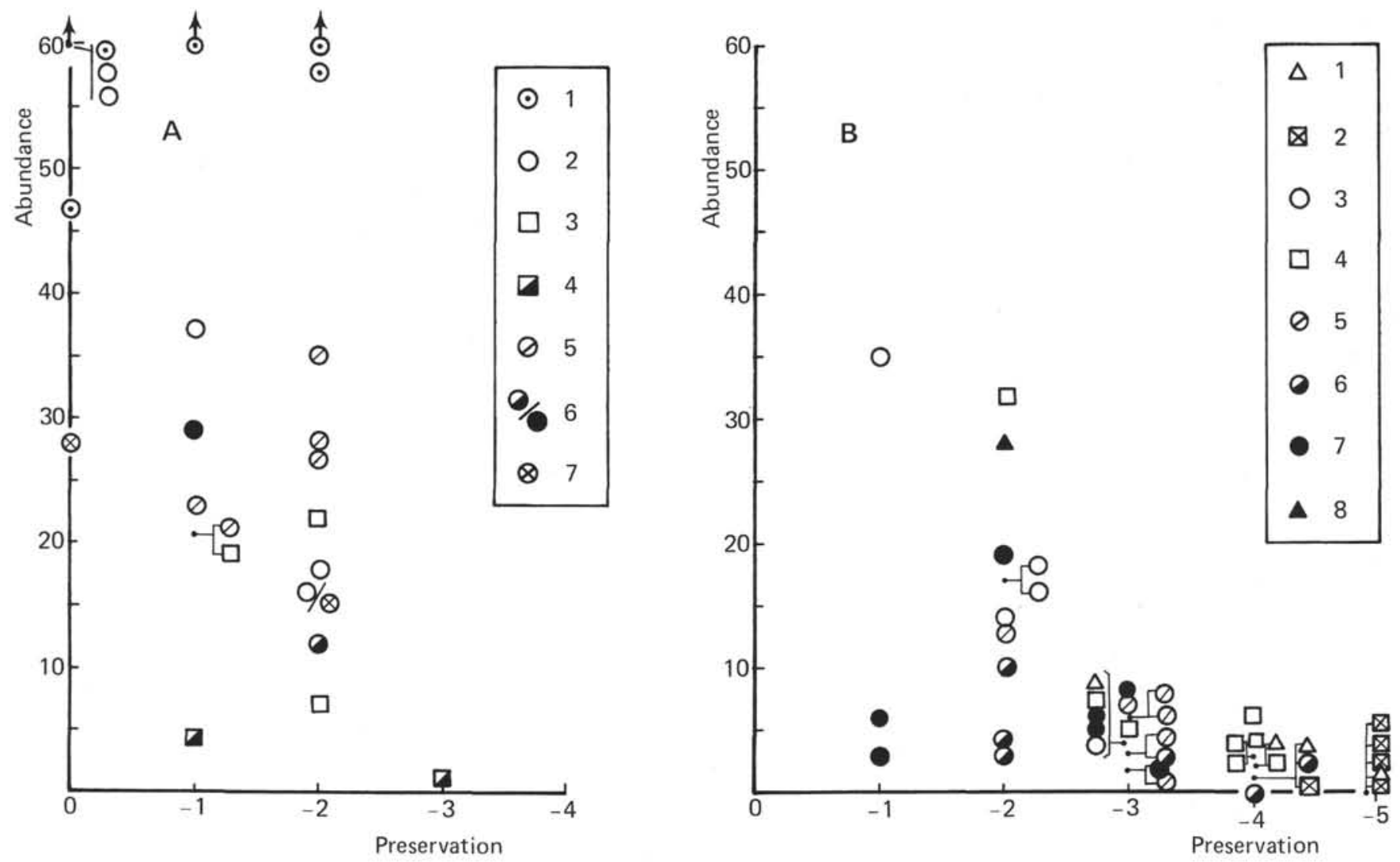

Figure 6. Plots of abundance (number of nannofossils specimen in a SEM at 2000X magnifications) and preservation (scale 0 to -5 , in order of decreasing preservation) of the calcareous nannofossils. Diagrams shown in Figures 2, 5, and 6 serve to delineate terrigenous dilution and carbonate dissolution processes. (A) Cores 398-2 to 398D-8: 1 and 2, pelagic deposits; 3 and 4, hemipelagic deposits; 5, turbiditic mud; 6, turbiditic silt and sand; 7, bottom-winnowed deposits. (B) Cores 398-2 to 398D-56: 1, 2, 3, and 4, deposits of differential pelagic settling; 5, turbiditic mud; 6, turbiditic silt; 7 , turbiditic sand; 8 , slump deposits.

ness, while the claystone type shows very positive skewness (Table 2, Figure 8B).

\section{Dilution, Dissolution, and Bottom Current Processes}

Sample points of the upper Cenozoic sediments from the suspended sediment regime, with the exception of the calcareous terrigenous mud (Type 4), that are plotted in the $\mathrm{F} / \mathrm{W}-\mathrm{B} / \mathrm{P}$ diagram tend to correlate by a regression line of the type $(\mathrm{F} / \mathrm{W}) \times(\mathrm{B} / \mathrm{P})^{\mathrm{a}_{1}}=$ $a_{o}$ (Figure 2A). This correlation may indicate that dissolution is the primary factor controlling value variations for the foraminiferal dissolution indexes of the pelagic deposits. That is, increased dissolution would result in proportionally higher $\mathrm{F} / \mathrm{W}$ and $\mathrm{B} / \mathrm{P}$ ratios. However, dynamic processes, such as bottom currents, and fluctuations in the influx rate of organic-rich terrigenous detritus may have also played a significant role in the observed compositional variations of this sediment group.

Other parameters, such as texture, help to define the relative influence of these dynamic factors and of detrital dilution. The analysis of pelagic deposits (Types 1 and 2 ) reveals that an increase in median diameter generally correlates with greater positive skewness (Table 1, dashed line in Figure 8A). An increase in bottom current activity would produce this result by winnowing fines and changing the skewness from negative to positive; i.e., dashed line in Figure 8A (cf. Huang and Watkins, 1977). As for dissolution processes, increases in bottom current activity would also be reflected in the foraminiferal indexes by higher $\mathrm{F} / \mathrm{W}$ ratios, due to breaking of both benthic and planktonic foraminifers, and by higher $\mathrm{B} / \mathrm{P}$ ratios, because of selective transport of planktonic foraminifers.

Hemipelagic deposits (Types 3 and 4) display the opposite textural relationship, as well as a greater range of sorting values than for pelagic deposits (Table 1, double dotted-dashed line in Figure 8A). However, no significant differences are observed between foraminiferal dissolution indexes of pelagic and hemipelagic deposits, although the latter are generally less preserved. On the contrary, the T/B ratios in the sand fraction and nannofossils abundance in the finegrained fraction, are evidence for much greater proportions of detrital particles in the hemipelagic than in the pelagic deposits. Thus, the textural and compositional characteristics of the calcareous-terrigenous sediment types are attributed to an enhanced input of detrital particles as well as to some dissolution of the calcareous components. 

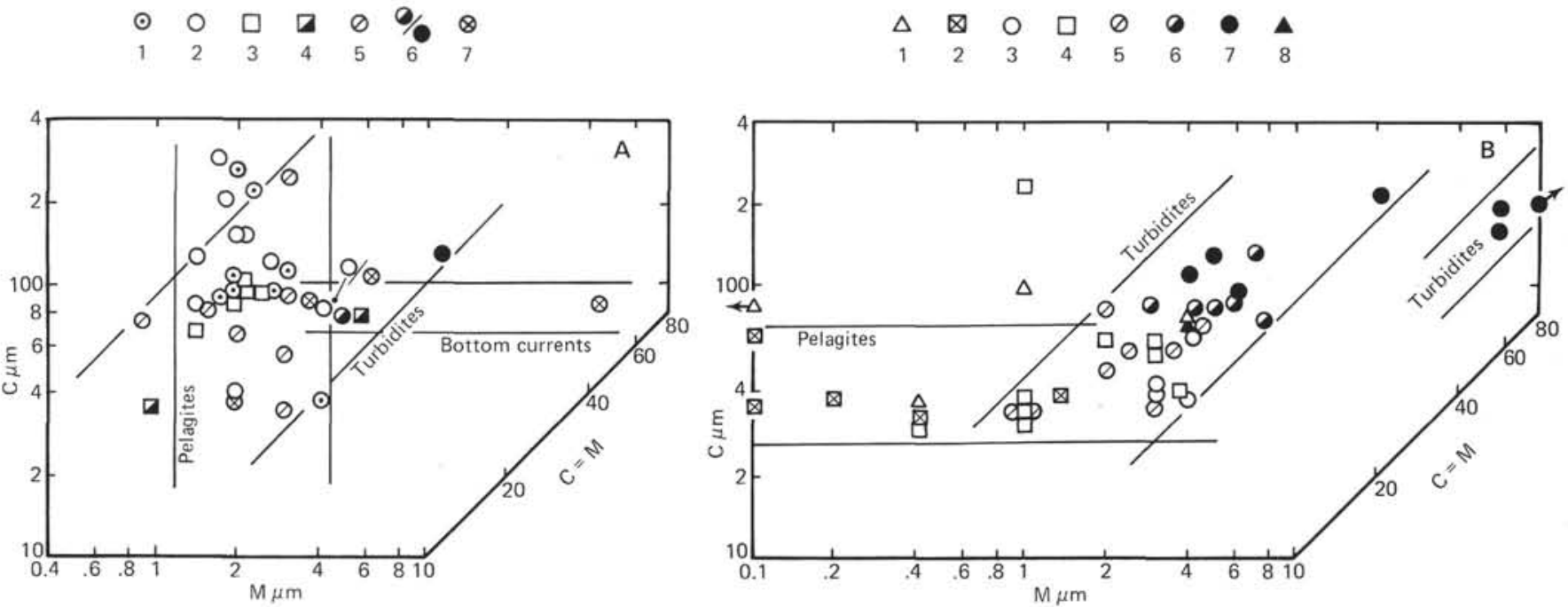

Figure 7. $C M(C$, centilo or cumulative $1 \%$ diameter; $M$, median, or cumulative $50 \%$ diameter ) diagrams of selected samples from Site 398. (A) Cores 398-2 to 398D-8: 1 and 2, pelagic deposits; 3 and 4, hemipelagic deposits; 5, turbiditic mud; 6, turbiditic silt and sand; 7, bottom-winnowed deposits. (B) Cores 398D-9 to 398D-56: 1, 2, 3, and 4, deposits of differential pelagic settling; 5, turbiditic mud; 6, turbiditic silt; 7, turbiditic sand; 8, slump deposits.

Dissolution processes are better developed in deposits from suspensates of the lower Cenozoic and Upper Cretaceous. The observed distribution of grain-size parameters from these pelagic sediments results from the limited size range of detrital particles and from the marked dissolution of the calcareous components. The skewness changes from negative to positive, the sorting becomes poorer, and the median grain-size decreases as dissolution of the calcareous components (foraminifers and nannofossils) increases (solid line in Figure 8B).

Previous discussion showed that a slight increase in bottom current activity develops the opposite trends in pelagic deposits of the upper Cenozoic segment. Moreover, the effect of dissolution on the grain-size parameters of pelagic sediments is similar to that of dilution by detrital lutite but in the opposite direction; i.e., increase dissolution develops deposits with a finer median size and more positive skewness, while enhanced input of detrital lutite results in coarser deposits with more symmetrical skewness (compare double dotteddashed line in Figure 8A and solid line in Figure 8B) In either case, the calcareous assemblages show marked differences in preservation, which makes possible the differentiation of one process from the other (see Plate 1, Figure 4 and 9; Plate 2, Figures 12 and 13). Examples of these three processes (dilution, dissolution, and bottom current activity) exist in the different types of deposits from differential pelagic settling represented in Figure 8.

\section{Winnowed Sediments}

Sediments deposited by contour-following bottom currents (contourite) have been extensively described in piston cores from the continental rise (Heezen and Hollister, 1971; Hollister and Heezen, 1972; Bouma and Hollister, 1973). Contourites are defined as sediments deposited by a relatively clean and slow moving contour following bottom circulation (Bouma and Hollister, 1973).

A few cores from Hole 398, containing relatively thin beds of multicolored oozes and chalks that are wavy or parallel laminated, were attributed to bottom current activity (Plate 1, Figure 2). These laminated sediments are distinctive from some classical contourites because: (1) they lack a noticeable terrigenous fraction; (b) their texture is usually silty clay and seldom clayey silt or sandy silt, and (c) cross-laminations or grading are generally absent. Occasionally some thin, ripple-laminated, terrigenous layers composed primarily of pyrite, glauconite, and biogenic tests are observed in these intervals. These deposits are more similar to classical contourites than to the products of other transport mechanisms, but they could be interpreted as placer and winnowed deposits produced by currents sweeping the bottom.

The laminated beds are usually unburrowed. In contrast, the interbedded pelagic sediments display intense bioturbation, with Zoophycos, Helminthoides, Mycellia, Chondrites, and some composite burrows. Basal contacts of the laminated beds are either gradational or sharp. Sharp basal contacts reflect noticeable bottom current activity which has removed sediment deposited earlier. This activity also seems to have affected the upper several centimeters of the underlying plastic sediments, as evidenced by stretching and overturning of burrows, and by microfaulting.

Total carbonate content is usually high (above $70 \%$ ) but decreases sharply, paralleling the increase in median size (Type 7 in Table 1, Figure 3A). Sediment texture ranges from silty clay (most abundant) to sandy silt (Figure 4A). Foraminiferal assemblages show the effect of dissolution and transportation (Figure $2 \mathrm{~A}$ ). The terrigenous to biogenic ratio is low for the fine-grained deposits and relatively high for the coarse type (Figure 5A). Calcareous nannofossil preservation 

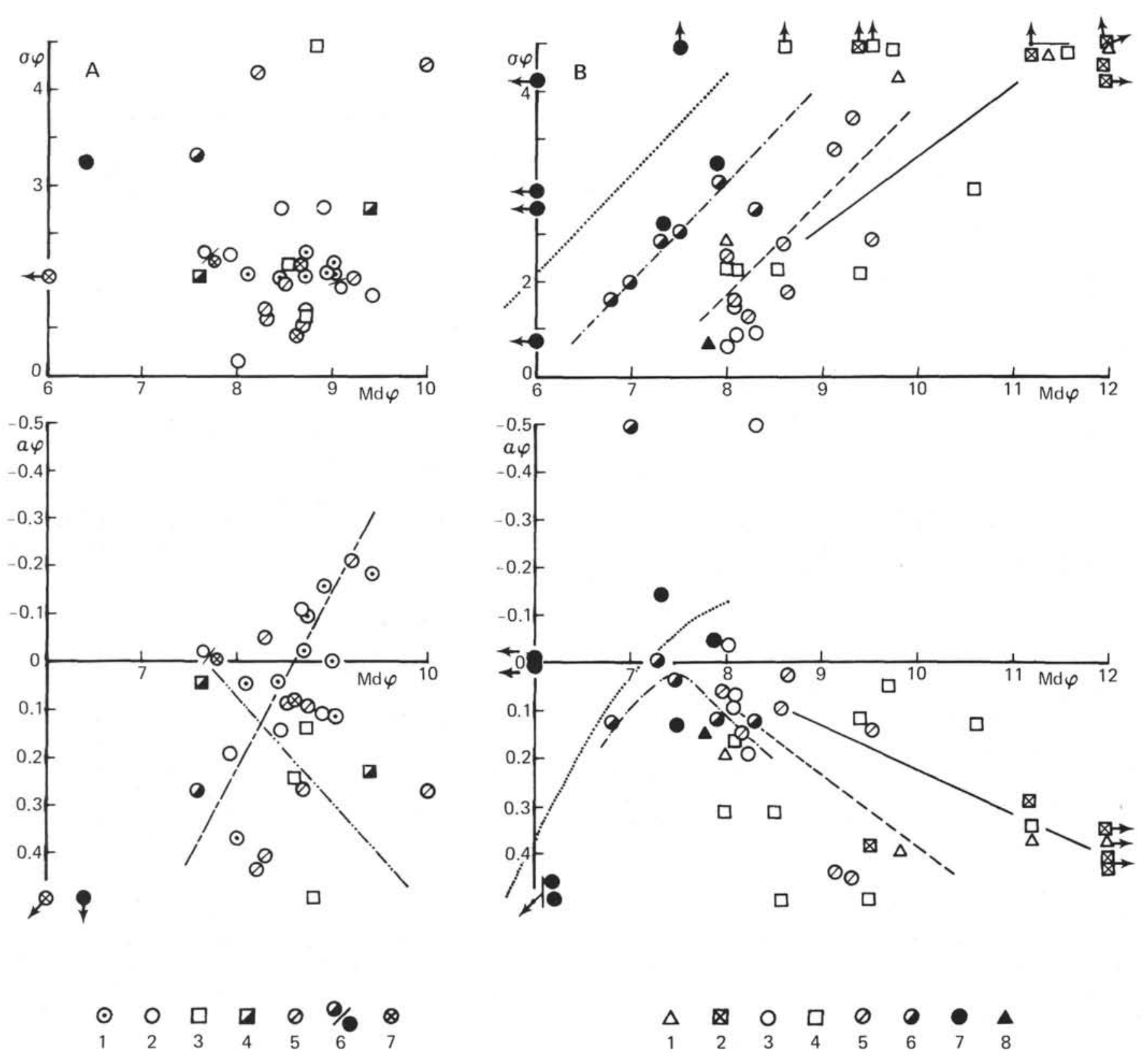

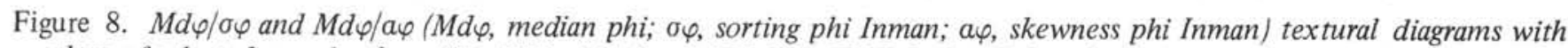
plots of selected samples from Site 398. (A) Cores 398-2 to 398D-8: 1 and 2, pelagic deposits (irregularly dashed line); 3 and 4, hemipelagic deposits (double dotted-dashed line); 5, turbiditic mud; 6, turbiditic silt and sand; 7, bottom-winnowed deposits (irregularly dashed line). (B) Cores 398D-9 to 398D-56: 1, 2, 3, and 4, deposits of differential pelagic settling (solid line); 5, turbiditic mud (dashed line); 6, turbiditic silt (dotted-dashed line); 7, turbiditic sand (dotted line); 8 , slump deposits.

is good, but abundance in relation to the biogenic pelagic sediments is low (Table 1, Figure 6A). Nannofossil assemblages are characterized by good size sorting (Plate 1, Figure 10).

The limited number of samples analyzed from this group reveals a great variability in the sediment size parameters. As discussed earlier, an increase in bottom water velocity changes the skewness of the sediment from negative to positive as the deposits becomes coarser (dashed line in Figure 8A). The end member of this bottom current activity is represented at Site 398 by carbonate-rich sandy-silts, which have high positive skewness, moderate sorting, and strong evidence of reworking or dissolution in the calcareous biogenic assemblages. A host of intermediate types occur between these deposits and the finer pelagic biogenic sediments, which are negatively skewed and very well preserved (Figures 4A and 8A).

Winnowed sediments increase in median size (M) paralleling the increase in bottom water velocity, but the centilo (C) decreases due to fragmentation and removal of the planktonic foraminiferal fraction. Therefore, sediments of this group define a pattern parallel to $\mathbf{M}$ in the $\mathbf{C M}$ diagram with maximum centilo value 
of about $100 \mu \mathrm{m}$ (Figure 7A). This value closely approximates the size of the coarsest clastic components (mostly quartz, pyrite, and glauconite) of the pelagic deposits.

\section{Turbiditic Sediments}

Sediments of this group are characterized in the $\mathrm{X}$-radiographs and split cores by an upward change in texture and sedimentary structures described by Bouma (1962) and others. The graded sequence of sediments also includes a turbiditic mud division, $\mathrm{Te}^{(\mathrm{t})}$, defined in detail by Rupke and Stanley (1974), Hesse (1975), Hesse and Butt (1976), and Maldonado and Stanley (1976a, b).

The upper Cenozoic strata generally contain base cut-out turbiditic beds. These predominantly muddy units commonly start with the $\mathrm{T}_{c}$ or $\mathrm{T}_{\mathrm{d}}$ divisions of the classic Bouma sequence (Figure 9; Plate 1, Figures 1, 2 , and 3 ). Turbidites are more complete, better developed, and more abundant in the lower Cenozoic (Plate 2, Figures 2, 3, and 4). These turbidites often begin with the $T_{b}$ division, while complete $T_{a-e}$ sequences are generally absent or poorly developed.

Three textural sediment types are recognized within this group: turbiditic mud (ooze and/or chalk), silt, and sand (Tables 1 and 2). Turbiditic muds (Type 5 in Tables 1 and 2; Plate 1, Figures 5 and 11; Plate 2, Figure 11) are characterized by a delicate basal lamination and poor-to-well-developed bioturbation. They usually show continuity and gradation in terms of structure and gross lithology with the sand-silt sediment types (cf., Rupke and Stanley, 1974; Hesse, 1975; Maldonado and Stanley, 1976b). Turbiditic silt (Type 6 in Table 2) is the most typical sediment type forming the base of the turbiditic beds. It is characterized by parallel and low-angle oblique lamination and, less frequently, by diverse types of ripples. Turbiditic sand is common in the lower Cenozoic (Type 7 in Table 2), and present in the Upper Cenozoic (Type 6 in Table 1, which comprises sand and silt types). This sediment type contains well-defined sedimentary structures including cross and oblique lamination, graded bedding and diverse types of ripples, and parallel lamination. The base of the turbiditic sequences is usually sharp and erosional, and locally displays scour and fill structures.

Total carbonate content varies between 8 and 75 per cent. The lower values are usually displayed by the silt beds in the lower Cenozoic (Tables 1 and 2, Figures 3 and 4). Compositionally, two mineralogical extremes occur in the sand type: a largely bioclastic-carbonate sand, and a predominantly terrigenous sand, with the presence of a host of intermediate types (Figure 3).

The turbiditic group includes sediments ranging in size from silty clay to silty sand (Figure 4 ). They are usually gradational and different categories are established on the basis of texture and sedimentary structures. The boundaries are placed where compositional changes are more apparent.

Foraminiferal assemblages of these deposits show varying effects of dissolution or transportation (Tables
1 and 2, Figures 4 and 6). Foraminiferal preservation indexes of the upper Cenozoic turbiditic sediments belong to Subclass 1 (Figure 2A), indicating that the transportation of these displaced units has a lesser effect on the fragmentation of the planktonic components than that of dissolution and bottom current activity observed in the pelagic deposits. The latter are characterized by higher F/W ratios; i.e., they usually belong to Subclass 2. No significant differences are observed in the benthic to planktonic ratios between turbiditic and pelagic deposits.

Turbiditic sediments of the lower Cenozoic show greater variation in preservation than turbidites of the upper Cenozoic (Figures 2B and 6B). The silt type is the most variable, and contains deposits which range from relatively well preserved (Index $B_{f}$ ) to very poorly preserved (Index $O$ ). Turbiditic muds of the lower Cenozoic generally display moderate preservation (Indexes $C_{l}$ and $D_{l}$ ).

Differences in the foraminiferal assemblage indexes of turbiditic sediments may be attributed to differential transport and deposition as well as to post-depositional dissolution of the calcareous components. Assuming that all other factors remain constant, post-depositional dissolution and the degree to which the calcareous components are affected, is controlled by the porosity (texture) and total carbonate content of the sediment. Thus, terrigenous-rich silt sediments that are moderately sorted, would be, a priori, the most affected by early diagenetic dissolution processes.

Turbiditic sediments of the lower Cenozoic define a broad pattern parallel to the limit $\mathrm{C}=\mathrm{M}$ in the $\mathrm{CM}$ diagram of Figure $7 \mathrm{~B}$. The $\mathrm{C} / \mathrm{M}$ ratio is about 15 . A similar, somewhat broader pattern is displayed by turbiditic deposits of the upper Cenozoic (Figure 7A). However, the coarsest sand sediments of the lower Cenozoic, with $\mathrm{M}$ above $40 \mu \mathrm{m}$, show a pattern displaced toward the limit $\mathrm{C}=\mathrm{M}$, with a $\mathrm{C} / \mathrm{M}$ ratio of about 3 (Figure 7B).

Turbiditic sediments display a wide range of skewness values and generally poor sorting (Tables 1 and 2 , Figure 8). Turbiditic muds of the rhythmic association generally have positive skewness values, while turbiditic sands frequently are characterized by almost symmetrical curves that are either slightly positive or negative skewed. Turbiditic sands that fall in the CM diagram close to the limit $\mathrm{C}=\mathrm{M}$ have strongly positive skewness values (Figures 7B and 8B). Each turbiditic sediment type is also characterized by a general tendency toward better sorting with an increase in median grain-size. This trend is best displayed by the silt type (dotted-dashed line in Figure 8B).

\section{Turbidity Currents}

The observed distribution of grain-size parameters may be interpreted in terms of dynamic processes of turbidity currents, as well as of the original composition of the deposits from which the turbidite flow develops. Based on foraminiferal assemblages and composition data, it appears that the turbiditic deposits originated from slides and slumps, of predominantly 
fine-grained slope deposits having foraminiferal ratios similar to the deep pelagic deposits. The resulting suspensions consist of a limited range of particle sizes transported by flows likely to deposit distal-type graded units (cf. Hampton, 1972).

Turbiditic deposits are characterized in CM diagrams by patterns parallel to the limit $\mathrm{C}=\mathrm{M}$. The $\mathrm{C} / \mathrm{M}$ ratio of these patterns is believed to reflect the nature of the turbidity current including density and velocity. Variations of this ratio are attributed to the differing nature of a turbidity current (Passega, 1957). High current density can result in high $\mathrm{C} / \mathrm{M}$ ratios. Thus, the two different patterns defined by turbiditic deposits of the lower Cenozoic could be attributed to different types of turbidity currents.

Other factors, however, can develop the two different patterns defined by turbidites of the lower Cenozoic. Possible factors include relative changes in the head and body thickness of a turbidity current, or hydraulic jump phenomena at the break in slope, when the turbidite flow passes from a steep to a gentle gradient (cf. Middleton, 1970; Komar, 1971, 1972). These processes affect the release of both the coarse and fine materials, as well as subsequent changes in the nature of the turbidity current beyond the break in slope. The break in slope deposit is characterized by very positive skewness and relatively good sorting (Figure 8B). Only a few thin beds of the lower Cenozoic seem to be representative of this process. As the turbidity current deaccelerated, more sediment settled out; the deposit became finer and more poorly sorted and tended toward negative skewness (dotted line in Figure 8B).

Silt and mud turbiditic deposits develop similar trends but the skewness increases towards positive values for sediments with median size finer than $5 \mu \mathrm{m}$ (Figure 8). This change in skewness may represent the rapid settling of the finer particles when a critical velocity is reached.

In summary, the marked differences observed in sedimentary structures and textures between the turbiditic sand, silt, and mud deposits, as well as the gradual changes within each sediment type, could be attributed either to: (1) an evolution of the characteristics of a single turbidite flow as the current progressed, or (2) a different nature for individual flows. Within an individual turbidity current, active deposition of each sediment type will occur when a critical velocity is reached. The transitions between different sediment types record changes in the nature of the flow.

\section{Mass-Gravity Sediments}

A number of beds from the lower Cenozoic at Site 398 were interpreted as deposits of mass transport processes, i.e., involving gravity-driven movements of mixtures of sediment particles and water. Types of mass-gravity deposits are differentiated on the basis of the degree of internal deformation. Slides, slumps, debris flows or mud flows, and turbidity currents have been indicated by several authors to be different transport steps of the same mechanism (cf. Heezen and Ewing, 1955; Dott, 1963; Hampton, 1972, 1975; Middleton and Hampton, 1973). Slumps, debris, and mud flow deposits are included in this section for descriptive purposes. Turbiditic deposits, which may be considered an end member of this sediment group, have been separately described because of their greater importance at Site 398.

Slump deposits, characterized at Site 398 by smallscale penecontemporaneous folding and faulting, are abundant in Core 398D-15 (Oligocene) and present in some cores of the Paleocene. Movement occurred along individual shear planes resulting in some internal deformation. The original bedding features of the slump deposits are, however, locally obvious by the present of multicolored, wavy laminated, nannofossil chalks (Plate 2, Figure 1). These displaced units have a higher total carbonate content (to $72 \%$ ) than in situ pelagic sediments, better foraminiferal and calcareous nannoplankton preservation, and lower terrigenous ratio (Type 8 in Table 2; Figures 2B, 5B, and 6B; Plate 2 , Figures 6 and 7). Sorting is moderately good and skewness positive (Figure 8B). Their observed composition and grain-size parameters indicate that the slump units are pelagic and winnowed sediment types derived from somewhat shallower depths than the in-situ sediments. On the basis of sedimentary structures, these sediments originally were produced mostly by bottom current activity. Moreover, bottom current activity, among other factors, may have developed the necessary instability in the source area to generate the slumps.

Pebbly mudstone deposits and unsorted massive admixtures of sand and mud are other sediment types present in the lower Cenozoic. Movement of a debris flow occurs along innumerable shear planes within the body of the material, which flows rather than slides. Homogeneous or massive bedding is the most characteristic sedimentary structure of such sediments (cf., Reineck and Singh, 1973). However, sometimes a poorly developed graded bedding is seen. This normally occurs in sediment that has scattered grains throughout a fine-grained matrix and displays a decrease in their amount and average grain size upward. Gravity faults with curved, concave upward planes usually define the basal and upper contact planes of the pebbly mudstone units. The larger clasts of these units reach 5 to $6 \mathrm{~cm}$ in diameter, but pebbles $1 \mathrm{~cm}$ in diameter are more typical. The most common grain-tograin relationship or fabric is of free and floating grains (cf. Pettijohn et al., 1972; Allen, 1962; Bouma and Pluenneke, 1975). The finer grained representatives of these deposits are a few centimeters to a few decimeters thick, completely homogeneous and without scattered pebbles. The term mud flow is applied to them (cf. Gary et al., 1973). Petrographic analysis of these sediments has not been attempted (see Bourbon, this volume). 


\section{FACIES DEFINITION AND EVOLUTION}

\section{Facies Associations}

The different types of sediment present in the cores can be grouped into associations. Two major types of associations are recognized: (a) rhythmic association, and (b) cyclic association. These are defined on the basis of petrologic and structural characteristics that show distinct natural vertical lithologic affinities. Each association reflects deposition resulting from either a specific sedimentary process (turbidity current) or a regionally important, large-scale environmental event (cf. climatic changes significant enough to alter water mass flow and distribution of water masses, eustatic oscillatory sea-level patterns, and biogenic production).

\section{Rhythmic Association}

The rhythmic association is composed of alternating turbiditic sequences and pelagic deposits (Plate 2, Figures 2, 3, and 4). Locally, it also contains pebbly mudstone and slump deposits, and less frequently, current-winnowed deposits. Each rhythm is formed by two divisions: (a) a basal turbidite division, and (b) a pelagic division (Figure 9). The basal contact of each rhythm is sharp and usually erosional. Thickness of the rhythms varies between 10 and $100 \mathrm{~cm}$, but most are 15 to $40 \mathrm{~cm}$ thick (Figure 10). Sedimentation rates in the early Cenozoic at Site 398 ranged between 3 and 10 meters per million years, and average about 7 $\mathrm{m} / \mathrm{m}$.y. (see Biostratigraphy, this volume). From these data, an average time span varying from 10,000 to 300,000 years can be estimated for the development of an individual rhythm. Most rhythms may represent about 18,000 to 50,000 years.

The turbidite division forms from 5 to 55 per cent of the total rhythm thickness, but more commonly ranges between 10 and 40 per cent. The turbiditic mud division is the best developed of the turbiditic sequence. It grades upward into the pelagic division of the rhythm.

Turbiditic sequences contain the most ubiquitous sediment types, of the section investigated. They include classic sand and silt types, as well as mud turbidites (Figure 9). Rarely is the complete Bouma (1962) sequence observed. Most of the turbidites are base cutout units of the Bouma division, i.e., $T_{b-c-d}, T_{c-d}$, or $T_{d}$.

Mud turbidites deposited below calcite compensation depth contain more total carbonate than the interbedded pelagic sediments (Plate 2, Figures 10 and 11). Calcium carbonate dissolution had little effect on the rapidly deposited turbidites, while the slowly settling pelagic particles were strongly affected (cf. Hesse, 1975). Mud turbidites below Core 398D-29 consist of light colored sediments containing between 36 and 74 per cent $\mathrm{CaCO}_{3}$. The intercalated yellowish red and greenish gray pelagic deposits usually contain less than 30 per cent $\mathrm{CaCO}_{3}$, or are carbonate free and show only minor traces $\left(<2 \% \mathrm{CaCO}_{3}\right)$ from below Core 398D50 to the top section of Core 398D-56. Sediments were deposited below calcite compensation depth in the stratigraphic section between the late Cenomanian and late Santonian (Cores 398D-56 to 398D-50), and
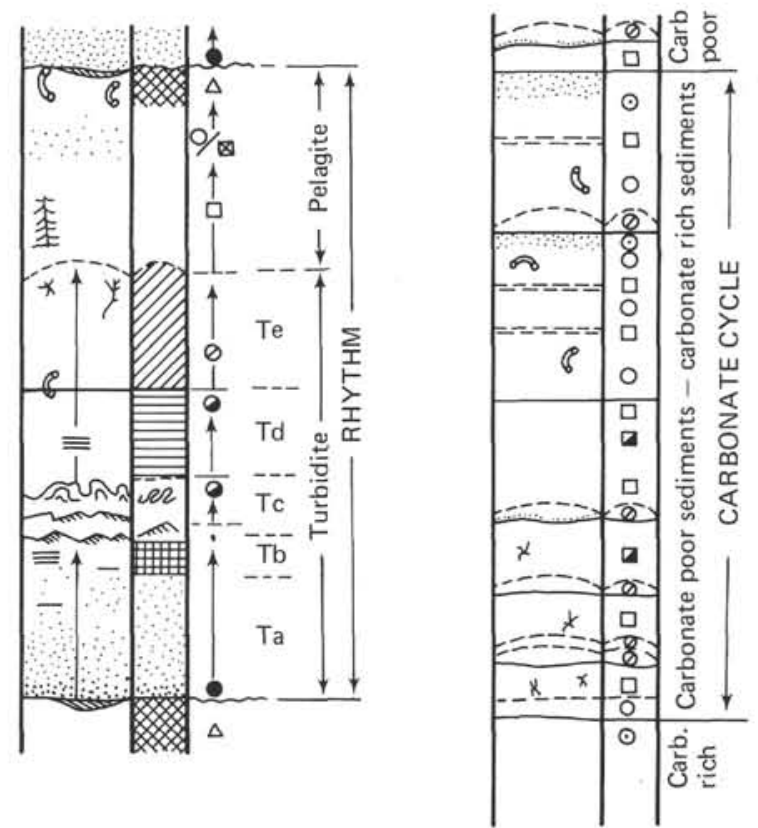

Figure 9. Schematic representation of single sedimentary units of the rhythmic and cyclic facies associations discussed in the text (not at scale). Symbols are used here as in Table 1 (upper Cenozoic) and Table 2 (lower Cenozoic and upper Cretaceous). Turbiditic sequence after Bouma (1962) and Rupke and Stanley (1974).

near CCD from there to the early Eocene (Cores 398D49 to $398 \mathrm{D}-29)$.

\section{Cyclic Association}

The cyclic association consists of alternating beds of pelagic biogenic sediments and transitional terrigenous sediments that repeatedly develop in a cyclic, asymmetrical manner (Plate 1, Figure 1). Each cycle consists of two orderly arranged divisions of different kinds of sediment. The basal division (a) is calcareous poor and consists of olive-gray, transitional biogenic and terrigenous sediments, i.e., hemipelagic deposits (Types 3 and 4 in Table 1). This division grades upward into (b) an upper calcareous-rich division of light-colored pelagic biogenic sediments (Figure 9). Mud turbidites and, less frequently, incomplete sand-to-silt turbiditic sequences occur irregularly throughout each cycle (Plate 1, Figures 1, 5, and 6). The turbidites are fewer in the upper division than in the lower and tend to be finer grained.

Carbonate cycles developed to varying degrees are observed at Site 398 from middle and lower Miocene to Pleistocene strata (Plate 1, Figures 1 and 3). Cycle thickness varies from 1.7 to 10 meters, but most of the cycles average 4 meters (Figure 10). Well-defined cycles have a thickness of about 2 to 3 meters. During the late Cenozoic, a sedimentation rate of about 40 meters per million years occurred at Site 398 (see Biostratigraphy, this volume). These estimates represent an average time span of about 50,000 to 250,000 years for the development of a cycle. Well-defined cycles may represent about 50,000 to 80,000 years. 


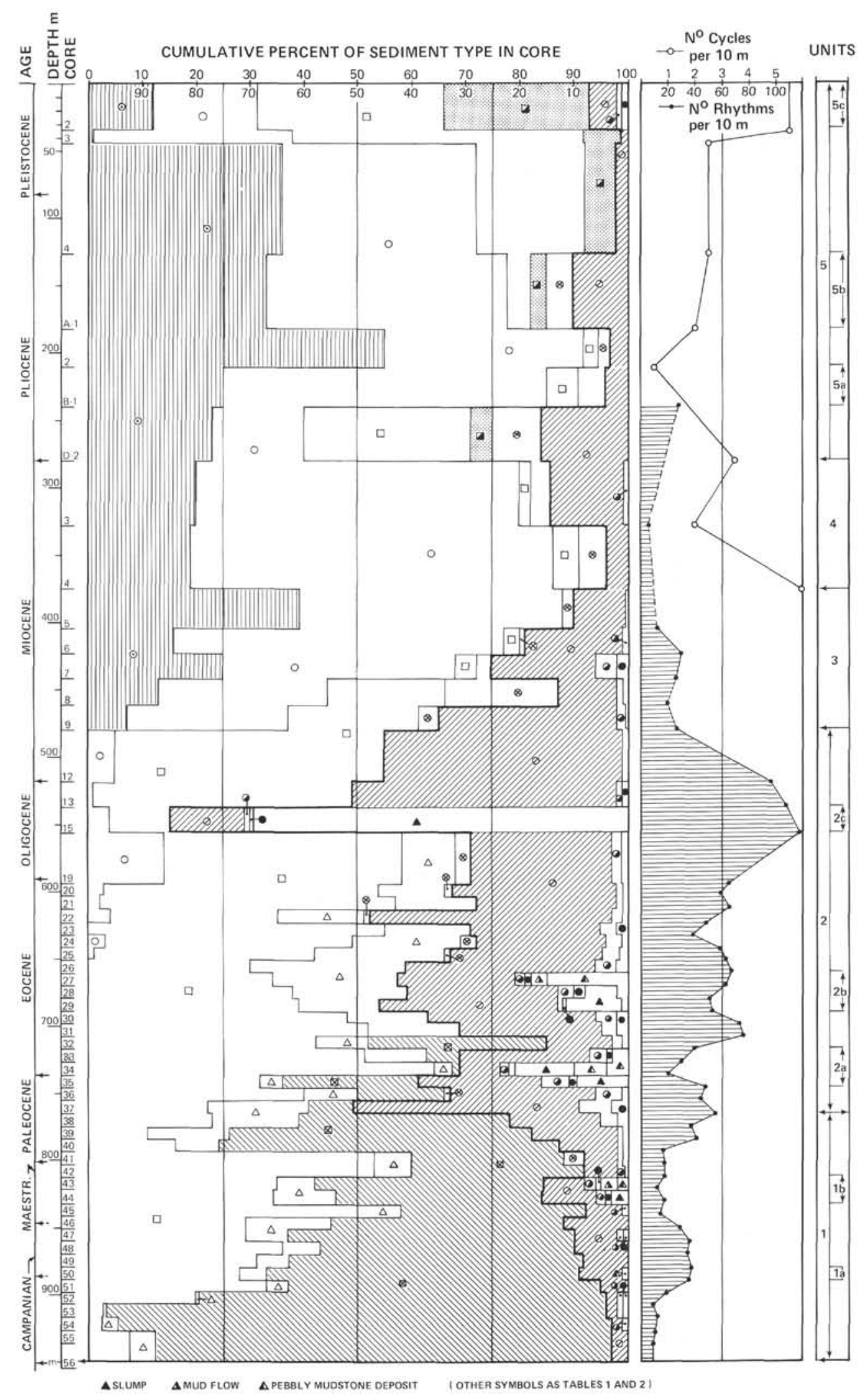

Figure 10. Cumulative per cent of sediment types, number of cycles and rhythms per 10 meters of sediment (notice differences in scale), and facies units for the upper Cretaceous and Cenozoic at Site 398. $\mathbf{\Lambda}$, slump deposits; $\mathbf{\Lambda}$, mud flow deposits; $\Delta$, pebbly mudstone deposits; other symbols as Tables 1 and 2 . Heavy line in the cumulative per cent of sediment type diagram separates mass-gravity flow deposits (turbidites, slumps, debris, and mud flow deposits) from pelagic, hemipelagic, and bottom-winnowed deposits. Discussion in the text. 
The basal contact between successive cycles is readily apparent in split cores and in X-radiographs. There is a sharp change between the calcareous pelagic sediments and the overlying transitional-terrigenous sediment. Each complete cycle seems to indicate the recurrence of similar processes and conditions in a sequential manner. The gradual transitions within each cycle represent an evolution of the environmental parameters, while the sharp contacts between cycles may be interpreted as large-scale events significant enough to alter the previous environmental conditions.

Cyclic carbonate sedimentation patterns are recognized to be a major characteristic of recent deep-sea sediments. Despite much recent effort and better understanding of dissolution processes, some controversy still exists concerning the relationship between cyclic sedimentation and the primary controlling factors for the distribution of calcium carbonate. Cyclic carbonate patterns in the equatorial Pacific were originally interpreted to be controlled by productivity (Arrhenius, 1952). Subsequent work associates carbonate minimum levels with enhanced interglacial dissolution (Berger, 1973; Thompson and Saito, 1974). Difficulties arose when the dissolution hypothesis was applied to Atlantic sediments. Gardner (1975) has observed enhanced dissolution during glacial episodes in equatorial Atlantic deep-sea sediments. This coincides with the description by Olausson $(1965,1971)$ of carbonate maximum levels corresponding with interglacials.

Other processes may have affected the down-core cyclic variation in calcium carbonate content. Several workers (Ruddiman, 1971; Hays and Perruzza, 1972) considered variations in the input of detrital clay to be the primary controlling factor for the distribution of calcium carbonate in the equatorial Atlantic. Thunell (1976a) described carbonate cyclic deep-sea sediments from the Gulf of Mexico that where characterized by enhanced dissolution during glacial episodes. In contrast to conventional bottom water dissolution hypothesis, Thunell (1976a) attributed the carbonate cycles to the combined effect of dissolution, as a result of shoaling of the lysocline and the decomposition of organic matter, as well as to terrigenous dilution.

A more complex carbonate cyclic pattern is reported in deep-sea sediments from the eastern Mediterranean. Sediment types form a repetitive sequence from bottom to top, of gray terrigenous mud to sapropel to calcareous ooze (Maldonado and Stanley, 1976a). Calcareous sediments of these cycles appear to develop best at times of maximum and minimum sea-level stands, while the terrigenous deposits are attributed to increased input of detrital sediments during periods of climatic and eustatic oscillations (Stanley and Maldonado, 1977; Maldonado and Stanley, 1977).

Cores 2, 3 and 4 from Hole 398D and Core 1 from Hole 398A (lower Pliocene-Plestocene) contain welldeveloped carbonate cycles. Basal terrigenous sediments of these cycles show the partial effect of dissolution of the calcareous components (Table 1, Figures $2 \mathrm{~A}$ and $6 \mathrm{~A}$ ). However, differences in calcareous assemblages between the basal and the top divisions of the cycle are not significant (Plate 1, Figures 4, 7, 8, and 9 ). This precludes the conclusion that the cyclic pattern has been only the result of dissolution.

The calcareous cycles must be explained at Site 398 as the result of a balance between increased noncalcareous dilution, and some calcite loss to dissolution during the development of the basal division of the cycle. The relative importance of each of these two processes acting in opposition to each other, is difficult to evaluate. Additional parameters, such as precise sedimentation rates, would be necessary for such an evaluation. On the basis of sediment composition and grainsize distribution, dilution by detrital particles may be the primary controlling factor. Dissolution of the calcareous components seems to be a secondary factor, that may have been favored by the higher content of organic matter of the terrigenous input. These two independent factors, dilution and dissolution, appear to respond in unison to produce the observed variations in calcium carbonate content. Other factors, such as bottom current activity and turbidity currents, have modified the predominant pelagic settling processes but they have a lesser effect in the development of the cyclic pattern.

Finally, it should be stressed that while the rhythmic pattern is a result of specific local sedimentary processes (turbidity current, mass-gravity), the cyclic pattern reflects major environmental changes. Regional studies elsewhere have shown that individual rhythms similar to those at Site 398 are difficult to correlate even in closely spaced cores (cf. Maldonado and Stanley, 1976b). In contrast, the carbonate cyclic pattern is a basin-wide phenomena that should be correlatable across extensive areas (cf. Berger, 1973; Gardner, 1975; Thunell, 1976a; Maldonado and Stanley, 1976a).

\section{Evolution of Facies in Time}

Total thickness of each sediment type was determined from DSDP Initial Core Descriptions (which has been slightly modified and completed on the basis of the results of this study). The cumulative per cent of sediment types in cores is represented in Figure 10. The diagram shows the evolution of sediment types at Site 398 and allows for the interpretation of the main sedimentary processes that have controlled the evolution of facies during the Upper Cretaceous and Cenozoic.

Five facies units are defined in this section as follows (bottom to top): 1, basal red mudstone and claystone pelagic unit; 2 , rhythmic, mass-gravity (turbidity current, slumping, debris flow) unit; 3 , transitional rhythmic turbiditic and pelagic chalk unit; 4, transitional pelagic chalk unit; 5 , cyclic pelagic-biogenic ooze unit. Facies changes are generally gradual, and the limits between the facies units are placed at the points of greater contrast (Figure 10).

\section{Facies Units}

The basal red mudstone and claystone pelagic unit (1) extends between the top of Core 398D-56 through- 
out Core 398D-38 inclusive (Figure 10). This facies unit is characterized by a great abundance of pelagic red claystone, 29 to 92 per cent of the total sediment thickness, with variable amounts of calcareous pelagic mudstone and subordinate proportions of turbiditic deposits (Plate 2, Figures 4 and 5). Two small sub-units, $l a$ and $l b$, are differentiated on the basis of the occurrence of thin debris and mud flow beds (Figure 10). The main sedimentary process for the development of this unit is pelagic settling. The prevailing regime of suspensate sedimentation recorded fluctuations of finegrained input and it was interrupted by "distal" type (cf. Bouma and Hollister, 1973) turbidity current incursions.

The lower section of this unit (Cores 398D-56 to 398D-50) was deposited below the calcite compensation depth. Pelagic sediments of the upper section contain greater proportions of carbonates and are characterized by an irregular pattern of carbonate-free sediments interbedded with calcareous-rich sediments. These fluctuations of carbonate content may be attributed to vertical migrations and pulses of the CCD interface at depths close to those prevailing at Site 398 during the Paleocene.

The rhythmic, mass-gravity unit (facies Unit 2) extends from Cores 398D-37 through 398D-12 (Plate 2, Figures 1 through 4 ). This unit is characterized by a relatively high proportion (average of 30 to $45 \%$ ) of mass-gravity deposits. Turbiditic sediments are the most abundant, and three small subunits $(2 a, 2 b$, and $2 c$ in Figure 10) contain slump, mud, and debris flow beds.

The principal sedimentary processes recorded in this unit include: (a) suspended sediment processes, influenced by fluctuations of fine-grained sediment input, bottom currents, biogenic productivity, and water masses distribution; and (b) gravity-controlled flows, of which turbidity currents predominate, while slumps and debris flows are subordinate.

Unit 2 records a relatively important influx of finegrained detrital sediments during the Paleogene and early Miocene at Site 398 . This influx resulted from the tectonic rejuvenation of the source lands during the Alpine orogeny. The time span embraced by facies Unit 2 coincides with the great development of the flysch and molasse orogenic facies in the Alpine belts of Spain. The tectonic influence is mainly reflected in the pebbly mudstone deposits. The age range of pebbles present in Core 398D-34 is approximately 40 million years, i.e., from Upper Cretaceous to Eocene (see Blechschmidt, this volume).

The transitional turbiditic and pelagic chalk unit (facies Unit 3) extends between Cores 398D-9 through 398D-5 (Figure 10). It is defined by the appearance of pelagic nannofossil-foraminiferal chalk (sediment Type 1 in Table 1) and a decrease in the number of rhythms. Bottom-winnowed sediments are ubiquitous and relatively abundant in Unit 3. Turbiditic sediments decrease upward in the section from the underlying unit as the rhythms become thicker.
Unit 3 represents a transitional facies from the rhythmic, mass-gravity facies towards a dominant pelagic settling sedimentation regime. This unit records a tendency towards an increase in the tectonic stability of the environment and/or a shifting away of the depocenters. The new sedimentary regime is clearly dominated by suspended settling processes, occasionally interrupted by "distal" type turbidite incursions. Bottom current activity is of temporal importance. This current activity may have caused small stratigraphic hiatuses, as observed in the Miocene (see Biostratigraphy, this volume).

The transitional pelagic chalk unit (facies Unit 4) is found in Cores 3 and 4 from Hole 398D (Plate 1, Figures 2 and 3 ). It is characterized by the presence of poorly defined cycles that alternate with turbiditic rhythms (Figure 10). Unit 4 is a transitional facies and together with Unit 3 records the transition from the rhythmic to the cyclic facies association.

The cyclic pelagic-biogenic ooze unit (5) extends from Core 398D-2 to the top of Site 398 (Plate 1, Figure 1). Pelagic foraminifer-nannofossil and transitional biogenic oozes (Types 1 and 2 in Table 1) are the predominant sediment types in this unit. Hemipelagic terrigenous-calcareous oozes (Types 3 and 4 in Table 1) and bottom-winnowed deposits alternate with the pelagic sediments. Turbiditic deposits are subordinate (average $5 \%$ and vary between 1 and $16 \%$ of the total sediment thickness) in this unit. Two subunits are characterized by the occurrence of well-developed carbonate cycles (Subunits $5 b$ and $5 c$ ). A third subunit ( $5 a$ ) formed by rhythms is also differentiated (Figure 10).

\section{Tectonic Activity, Terrigenous Input, and Sedimentation}

The relationship of the debris flow deposits to tectonic activity and reactivation of proximal escarpments, or to distal debris flows from large sediment slides of the continental margin is difficult to determine. Debris flow deposits that extend over a gentle slope a distance of several hundred kilometers from the generating slide have been reported from the Spanish Sahara continental margin (Embley, 1976). These mass-gravity deposits apparently were emplaced by quite mobile flows. In other instances, the unstratified wedges of mass-flow deposits likely were emplaced very rapidly and lie directly adjacent to slide scarps, i.e., on the North American margin (Stanley and Silberberg, 1969; Stanley and Unrug, 1972; Embley, 1976). Debris flow deposits are characterized in deep water by lens-shaped bodies of transitional to well-stratified pelagic sediments and turbidites. Similar highly stratified acoustic reflectors are observed on the seismic records of Units 1 and 2 (see Reflection Profiles, this volume). Stanley and Silberberg (1969) have suggested that large sediment slides may be related to glacial-interglacial sea-level changes. At Site 398, however, the relationship of debris flows to major oceanographic or terrestrial events is not yet apparent.

The tectonic significance of the turbiditic facies is also not straightforward. The rhythmic facies of Unit 2 
could be interpreted either as a distal fan facies association without tectonic influence, or as a "flysch"-like tectonic facies. In both cases, the turbiditic to pelagic and the terrigenous to mud ratios of Unit 2 is low in comparison to well-known flysch basins (cf. Bouma 1962; Dzulynski and Walton, 1965; Hesse, 1975) or to some ancient and recent deep-sea fan models (cf. Walker and Mutti, 1973; Nelson and Kulm, 1973). Turbiditic facies similar to Unit 2 are reported from several deep-sea environments in the Mediterranean Sea (Huang and Stanley, 1972; Rupke and Stanley, 1974; Kelling et al., in press). Rhythmic turbiditic facies with low sand-to-mud ratio in the Mediterranean Sea are characteristic of the distal continental margin environments, far removed from major sources of sediments (Maldonado and Stanley, 1976b, 1977). These facies generally have no tectonic implications and are developed mainly as a result of the displacement of the sedimentary depocenter across the shelf during eustatic sea-level changes.

Therefore, facies Unit 2 may be attributed to a distal margin environment in an area of low terrigenous input. Most of the turbiditic deposits are calcareous in nature and probably originated from large slides and slumps of sediments triggered on the upper slope. The rhythmic development of these facies could represent the distal manifestation of the alpine orogeny. This tectonic activity may have affected sedimentation in two possible ways: by shifting the depocenters closer to Site 398 , or by creating the necessary instability to produce the slides and slumps.

Changes in the terrigenous input at Site 398 are also observed in the cyclic facies association. Well-developed cycles in this facies are formed from a relatively high proportion of hemipelagic, bottom winnowed, and/or turbiditic deposits. Most of the cyclic facies unit (5), however, is represented by poorly developed cycles. They are characterized by a relatively thin basal calcareous-poor division and rather thick cycles (Figure $10)$. Fluctuations in fine-grained terrigenous input, bottom currents, productivity, and water mass distribution are the main sedimentary factors modifying the predominant pelagic settling regime. During the Quaternary, the cyclic development of the unit (5) is attributed to the effect of climatic and eustatic oscillations (cf. Olausson 1965, 1971; Ericson and Wollin, 1968; Ruddiman, 1971; Hays and Perruzza, 1972; Gardner, 1975). It is surmised that during eustatic low sea-level stands, rivers carried increased amounts of sediment onto the subaerially exposed continental shelf and further seaward onto the continental margin. This dilution by terrigenous sediment input seems to be the primary controlling factor for the development of carbonate cycles at Site 398.

\section{SUMMARY}

1. Four prominent sedimentary processes have controlled the Upper Cretaceous and Cenozoic evolution and distribution of facies at Site 398: differential pelagic settling, bottom currents, turbidite flows, and other mass-gravity processes. Suspended sediment processes are the most important and have been modified by fluctuations of fine-grained sediment input, bottom current activity, biogenic productivity, and water masses distribution.

2. Sediment types within these four genetic types are defined on the basis of compositional and textural parameters. Sediments attributed to pelagic settling are structurally homogeneous. They form a continuous spectrum grading from carbonate-rich biogenic nannofossil-foraminiferal ooze (pelagic deposits) to calcareous terrigenous mud (hemipelagic deposits), to carbonate-free claystone (pelagic deposits developed below CCD). Three main factors have influenced the distribution of pelagic sediments: terrigenous dilution, dissolution of the calcareous components, and bottom current activity. Terrigenous dilution and carbonate dissolution develop similar trends in the grain-size parameters of pelagic sediments but in opposite directions. However, abundance and preservation of calcareous biogenic assemblages helps to determine which of these two factors was of greater importance for the development of a specific sediment type. The effect of bottom current activity is well defined in the textural and compositional parameters of pelagic sediments.

3. Turbiditic sediments show noticable variations of sedimentary structures and textures in the sand, silt, and mud types. Moreover, deposits of each sediment type are characterized by gradual change of the compositional parameters. Most of the turbiditic deposits may have been generated from slumps and slides of fine-grained sediments from the slope. The variable composition of the turbiditic sediments at Site 398 may be attributed either to a change of the characteristics of a single turbidite flow as the current progresses, or to a difference in the spawning area for individual flows.

4. Winnowed and mass-gravity (excluding turbidites) sediments are less abundant, although they are locally well developed. Winnowed deposits record noticeable bottom current activity that may have caused stratigraphic hiatuses. Some debris and mud flow deposits could be related to tectonic activity. Debris flow deposits may have been produced by mobile flows generated from large sediment slides.

5. Two facies associations are defined: (a) rhythmic association, and (b) cyclic association. The rhythmic association is developed by alternating turbiditic sequences and pelagic deposits. Each rhythm results from a specific sedimentary process (turbidity current) of local importance to the scale of the basin. The cyclic association consists of regularly arranged beds of pelagic, biogenic, carbonate-rich sediments and transitional, terrigenous, carbonate-poor sediments that repeat in a cyclic, asymmetrical manner. Each cycle indicates the recurrence of similar processes and conditions. Carbonate cycles are best explained at Site 398 as result of a balance between increased non-calcareous dilution, as well as some calcite loss to dissolution during the development of the basal division of the cycle. Dilution by detrital particles seems to be the primary controlling 
factor. Cyclic sedimentation reflects a basinwide evolution that should be correlatable across extensive areas.

6. Five vertical facies units were differentiated for the Upper Cretaceous to Cenozoic at Site 398. Facies Unit 2 is the most characteristic representative of the rhythmic facies association; facies Unit 5 typifies the cyclic facies association. Facies Unit 2 contains a relative abundance of mass-gravity deposits (mostly turbidites) and to a lesser extent, slumps, mud, and debris flow deposits. The other four units are composed of predominantly pelagic and hemipelagic deposits, which generally comprise more than 80 per cent of the total sedimentary thickness.

7. Unit 1 (Upper Cretaceous-Paleocene) is a dominantly pelagic facies developed below or near the carbonate compesation depth. Unit 2 (Paleocene-lower Miocene) records a relatively important influx of finegrade detrital sediments to the basin. This influx reflects the tectonic rejuvenation of the sourcelands during the Alpine orogeny. Units 3 and 4 (Miocene) are a transitional facies that record the passing from the rhythmic to the cyclic facies association. Unit 5 (Pliocene-Pleistocene) reflects major changes in environmental conditions. This unit reflects climatic and eustatic oscillations during the Quaternary.

\section{CONCLUSIONS}

The Upper Cretaceous and Cenozoic deposits at Site 398 , located on the tectonically passive, distal North Atlantic continental margin off Portugal, are predominantly the result of the suspended sediment regime. The sedimentary facies of this margin also show deposition from mass transport processes and bottom current activity. Mass-gravity deposits, although volumetrically less important than the pelagic sediments, are very significant for the interpretation of tectonic events and terrigenous input. The effect of bottom currents was limited at this site, unlike at some other passive continental margins (e.g, the western North Atlantic). Only a few beds in core sections at Site 398 were interpreted as deposits from bottom current activity, as shown by variations in the composition of the finegrained pelagic deposits.

The compositional parameters (total carbonate content, grain size, terrigenous and biogenic components, and sedimentary structures) of the sediments were used to define specific depositional processes. On the basis of the importance of the different sediment types, five facies units were defined in the Upper Cretaceous and Cenozoic strata at Site 398 . These units were primarily differentiated by the relative proportions of pelagic to mass-gravity deposits and, secondarily, by the type of sedimentary processes.

The final interpretation of some of the specific aspects of the depositional environment, however, remains relatively uncertain because the results are largely based on a single locality. Further regional studies are needed to substantiate the interpretations reported here.

\section{ACKNOWLEDGMENTS}

Financial support for the analytical part of this work was provided by the Consejo Superior de Investigaciones Científicas of Spain. The Deep Sea Drilling Project funded the Xradiography of cores, J. Fiske of DSDP, East Coast Repository, made the X-radiographs of selected core sections and core slices were X-radiographed by J. P. Réhault. I thank G. Blechschmidt for determining the preservation states of calcareous nannofossils and valuable discussions. Drs. G. Bleschschmidt, R. J. Knight, D. J. Stanley, and O. Weser critically reviewed the text. I express special thanks to all of them for their many helpful suggestions that improved the original manuscript.

\section{REFERENCES}

Allen, J. R. L., 1962. Petrology, origin and deposition of the highest Lower Old Red Sandstone of Shropshire, England, J. Sediment. Petrol., v. 32, p. 657-697.

Arrhenius, G., 1952. Sediment cores from the east Pacific, Report, Swedish Deep-Sea Exped., v. 5, p. 1-227.

Berger, W. H., 1973. Deep-sea carbonates: Pleistocene dissolution cycles, Journal of Foraminiferal Res. , v. 3, p. $187-$ 195.

Blechschmidt, G., 1976. Biostratigraphy of calcareous nannofossils: Leg 34, Deep Sea Drilling Project. In Yeats, R. S., Harts, S. R., et al., Initial Reports of the Deep Sea Drilling Project, v. 34: Washington (U. S. Government Printing Office), p. 705-712.

Bouma, A. H., 1962. Sedimentology of some flysch deposits, a graphic approach to facies interpretation: Amsterdam (Elsevier).

1964. Notes on X-ray interpretation of marine sediments, Marine Geol., v. 2, p. 278-309.

1975. Sedimentary structures of Phillippine Sea and Sea of Japan sediments, DSDP Leg 31. In Karig, D. E., Ingle, J. C., et al., Initial Reports of the Deep Sea Drilling Project, v. 31: Washington (U.S. Government Printing Office), p. 471-488.

Bouma, A. H. and Hollister, C. D., 1973. Deep ocean basin sedimentation. In Middleton, G. V. and Bouma, A. H. (Eds.), Turbidites and deep water sedimentation: Anaheim (S.E.P.M. Pacific Section), p. 79-118.

Bouma, A. H. and Pluenneke, J. L., 1975. Structural and textural characteristics of debrites from the Phillippine sea. In Karig, D. E., Ingle, J. C., et al., Initial Reports of the Deep Sea Drilling Project, v. 31: Washington (U.S. Government Printing Office), p. 497-505.

Dott, R. H., 1963. Dynamics of subaqueous gravity depositional processes, Am. Assoc. Petrol. Geol. Bull., v. 47, p. 104-128.

Dzulynski, S. and Walton, E. K., 1965. Sedimentary features of flysch and greywacke: New York (Elsevier).

Embley, R. W., 1976. New evidence for occurrence of debris flow deposits in the deep sea, Geology, v. 4, p. 371-374

Emery, K. O., Uchupi, E., Phillips, J. D., Bowin, C. O., Bunce, E. T., and Knott, S. T., 1970. Continental rise off eastern North America, Am. Assoc. Petrol. Geol. Bull., v. 54, p. 44-108.

Ericson, D. B. and Wollin, G., 1968. Pleistocene climates and chronology in deep-sea sediments, Science, v. 162, p. 1227-1234.

Gardner, J. V., 1975. Late Pleistocene carbonate dissolution cycles in the eastern equatorial Atlantic. In Sliter, W. V., Bé, A. W. H., and Berger, W. H. (Eds.), Dissolution of 
deep-sea carbonates: Cushman Found. Foram. Research Spec. Publ., v. 13, p. 129-141.

Gary, M., Mcafee, R., Jr., and Wolf, C. L. (Eds.), 1973. Glossary of geology. Second ed., Washington (Am. Geol. Institute).

Hampton, M. A., 1972. The role of subaqueous debris flow in generating turbidity currents, J. Sediment. Petrol., v. 42, p. 775-793.

1975. Competence of fine-grained debris flows, J. Sediment. Petrol., v. 45, p. 834-844.

Hays, J. D. and Perruzza, A., 1972. The significance of calcium carbonate oscillations in eastern equatorial Atlantic deep-sea sediments for the end of the Holocene warm interval, Quaternary Research, v. 2, p. 355-362.

Heezen, B. C. and Ewing, G. M., 1955. Orleansville earthquake and turbidity currents, Am. Assoc. Petrol. Geol. Bull., New York (Oxford University Press).

Heezen, B. C. and Hollister, C. D., 1971. The face of the deep: New York (Oxford University Press).

Hesse, R., 1975. Turbiditic and non-turbiditic mudstone of Cretaceous flysch sections of the East Alps and other basins, Sedimentology, v. 22, p. 387-416.

Hesse, R. and Butt, A., 1976. Paleobathymetry of Cretaceous turbidite basins of the East Alps relative to the calcite compensation level, The Journal of Geology, v. 34, p. 505533.

Hollister, C. D. and Heezen, B. C., 1972. Geologic effects of ocean "bottom currents" Western North Atlantic. In Gordon A. L. (Ed.), Studies in physical oceanography: New York (Gordon \& Breach), v. 2, p. 37-66.

Huang, T. C. and Goodell, H. H., 1970. Sediments and sedimentary processes of eastern Mississippi Cone, Gulf of Mexico, Am. Assoc. Petrol. Geol. Bull., v. 54. p. 2070-2100.

Huang, T. C. and Stanley, D. J., 1972. Western Alboran Sea: sediment dispersal, ponding and reversal of currents. In Stanley, D. J. (Ed.), The Mediterranean Sea: A natural sedimentation laboratory: Stroudsburg (Dowden, Hutchinson and Ross), p. 512-559.

Huang, T. C. and Watkins, N. D., 1977. Contrasts between the Brunhes and Matuyama sedimentary records of bottom water activity in the South Pacific, Marine Geol., v. 23 , p. $133-132$.

Inman D. L. and Nordstrom, C. E., 1971. On the tectonic and morphologic classification of coasts, The Journal of Geology, v. 79, p. 1-21.

Kelling, G. and Stanley, D. J., 1976. Sedimentation in canyon, slope, and base-of-slope environments. In Stanley, D. J. and Swift, D. J. P. (Eds.), Marine sediment transport and environmental management: New York (John Wiley and Sons, Inc.), p. 379-435.

Kelling, G., Maldonado, A., and Stanley, D. J., in press. Salt tectonics and basement fractures: key controls of recent sediment distribution on the Balearic Rise, western Mediterranean, Smithsonian Contrib. Mar. Sci., Washington, D.C.

Komar, P. D., 1971. Hydraulic jumps in turbidity currents, Geol. Soc. Am Bull., v. 82, p. 1477-1488.

1972. Relative significance of head and body spill from a channelized turbidity current, Geol. Soc. Am. Bull., v. 83, p. 1151-1156.

Maldonado, A. and Stanley, D. J., 1976a. The Nile Cone: submarine fan development by cyclic sedimentation, $\mathrm{Ma}$ rine Geol., v. 20, p. 27-40. 1976b. Late Quaternary sedimentation and stratigraphy in the Strait of Sicily, Smithsonian Contrib. Earth Sci., Washington, v. 16.

1977. Nile Cone depositional processes and patterns in the late Quaternary. In Stanley, D. J. and Kelling, G. (Eds.), Sedimentation in submarine canyons, fans, and trenches: Stroudsburg (Dowden, Hutchinson and Ross), p. 239-257.

Maldonado, A., Riba, O., and Solé, R., 1973. Programa de computador para el cálculo granulométrico por medio del análisis con el hidrómetro, Bol. Geol. y Minero, I. G. M. E. Madrid, v. 84 , p. $438-446$.

Middleton, G. V., 1970. Experimental studies related to problems of flysch sedimentation. In Lajoie J. (Ed.), Flysch sedimentology in North America, Geol. Assoc. Can. Spec. Paper, v. 7, p. 253-272.

Middleton, G. V., and Hampton, M. A., 1973. Mechanics of flow and deposition. In Middleton, G. V. and Bouma A. H. (Eds.), Turbidites and deep water sedimentation: Anaheim (S.E.P.M. Pacific Section), p. 1-38.

Nelson, C. H. and Kulm, V., 1973. Submarine fans and channels. In Middleton, G. V. and Bouma, A. H. (Eds.), Turbidites and deep water sedimentation: Anaheim (S.E.P.M. Pacific Section), p. 39-78.

Olausson, E., 1965. Evidence of climatic changes in North Atlantic deep-sea-cores, with remarks on isotope paleotemperature analysis, Progress in Oceanography, v. 3, p. 221-252.

, 1971. Quaternary correlations and the geochemistry of oozes. In Funnel, B. M. and Riedel W. R. (Eds.), Micropaleontology of the oceans: Cambridge (Cambridge University Press), p. 375-398.

Passega, R., 1957. Texture as characteristic of clastic deposition, Am. Assoc. Petrol. Geol. Bull., v. 41, p. 830-847.

Passega, R. and Byramjee, R., 1969. Grain-size image of clastic deposits, Sedimentology, v. 13, p. 233-252.

Pettijohn, F. J., Potter, P. E., and Siever, R., 1972. Sand and sandstone: New York (Springer Verlag).

Reineck, H. E. and Singh, I. B., 1973. Depositional sedimentary environments: New York (Springer Verlag).

Ruddiman, N. F., 1971. Pleistocene sedimentation in the equatorial Atlantic. Stratigraphy and faunal paleoclimatology, Geol. Soc. Am. Bull., v. 82, p. 283-302.

Rupke, N. A. and Stanley, D. J., 1974. Distinctive properties of turbiditic and hemipelagic mud layers in the AlgéroBalearic Basin, Western Mediterranean Sea, Smithsonian Contrib. Earth Sci., v. 13.

Shepard, F. P. and Dill, R. F., 1966. Submarine canyons and other sea valleys: Chicago (Rand McNally).

Stanley, D. J. and Silberberg, N., 1969. Recent slumping on the continental slope off Sable Island Bank, southeast Canada, Earth and Planet. Sci. Letters, v. 6, p. 123133.

Stanley, D. J. and Maldonado, A., 1977. Nile Cone: Late Quaternary stratigraphy and sediment dispersal, Nature, v. 266 , p. $129-135$.

Stanley, D. J. and Unrug, R., 1972. Submarine channel deposits, fluxoturbidites, and other indicators of slope and base-of-slope environments in modern and ancient marine basins. In Rigby, J. K. and Hamblin, W. K. (Eds.), Recognition of ancient and modern sedimentary environments: Soc. Econ. Paleontologists and Mineralogists Spec. Publ., v. 16 , p. $287-340$. 
Thompson, P. R. and Saito, T., 1974. Pacific Pleistocene sediments: planktonic foraminiferal dissolution cycles and geochronology, Geology, v. 2, p. 333-335.

Thunell, R. C., 1976a. Calcium carbonate dissolution history in Late Quaternary deep-sea sediments western Gulf of Mexico, Quaternary Research, v. 4, p. 281-297. 1978b. Optimus indices of calcium carbonate dissolution in deep-sea sediments, Geology, v. 4, p. 525-528. Walker, R. G. and Mutti, E., 1973. Turbidite facies and facies associations. In Middleton, G. V. and Bouma, A. H. (Eds.), Turbidite and deepwater sedimentation: Anaheim (S.E.P.M. Pacific Section), p. 119-157. 

PLATE 1

Scanning electron microscope photographs of selected upper Cenozoic sediment types at Site 398; also, photographs of split cores with location of samples and schematic representation of lithologic sections.

Figure $1 \quad$ Well-developed carbonate cycles.

Figure 2 Laminated beds (winnowed sediments) interbedded with pelagic sediments displaying intense bioturbation.

Figure 3 Pelagic deposits alternating with turbiditic mud and hemipelagic beds which develop poorly defined cycles.

Figures 4, 9 Hemipelagic deposits with low abundance of wellpreserved nannofossils; dolomite crystal in 9, arrow, shows some dissolution.

Figures 5, 6 Turbiditic mud and sand, notice differences of size and sorting in the nannofossil assemblages between the sand (6) and the mud (5) types.

Figures 7, 8 Pelagic deposits with high abundance of wellpreserved nannofossils.

Figure 10 Winnowed sediment characterized by good sorting of the nannofossil assemblages.

Figure 11 Turbiditic mud showing fragmentation of nannofossils. Symbols as for Table 1 and Figure 9. 
PLATE 1
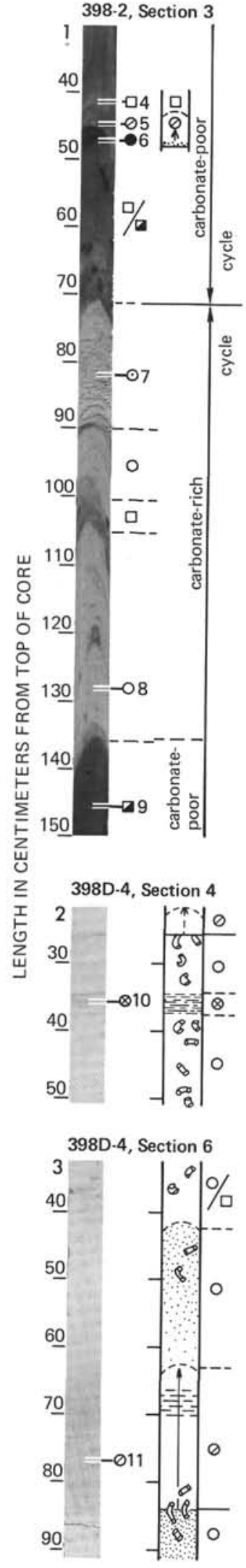
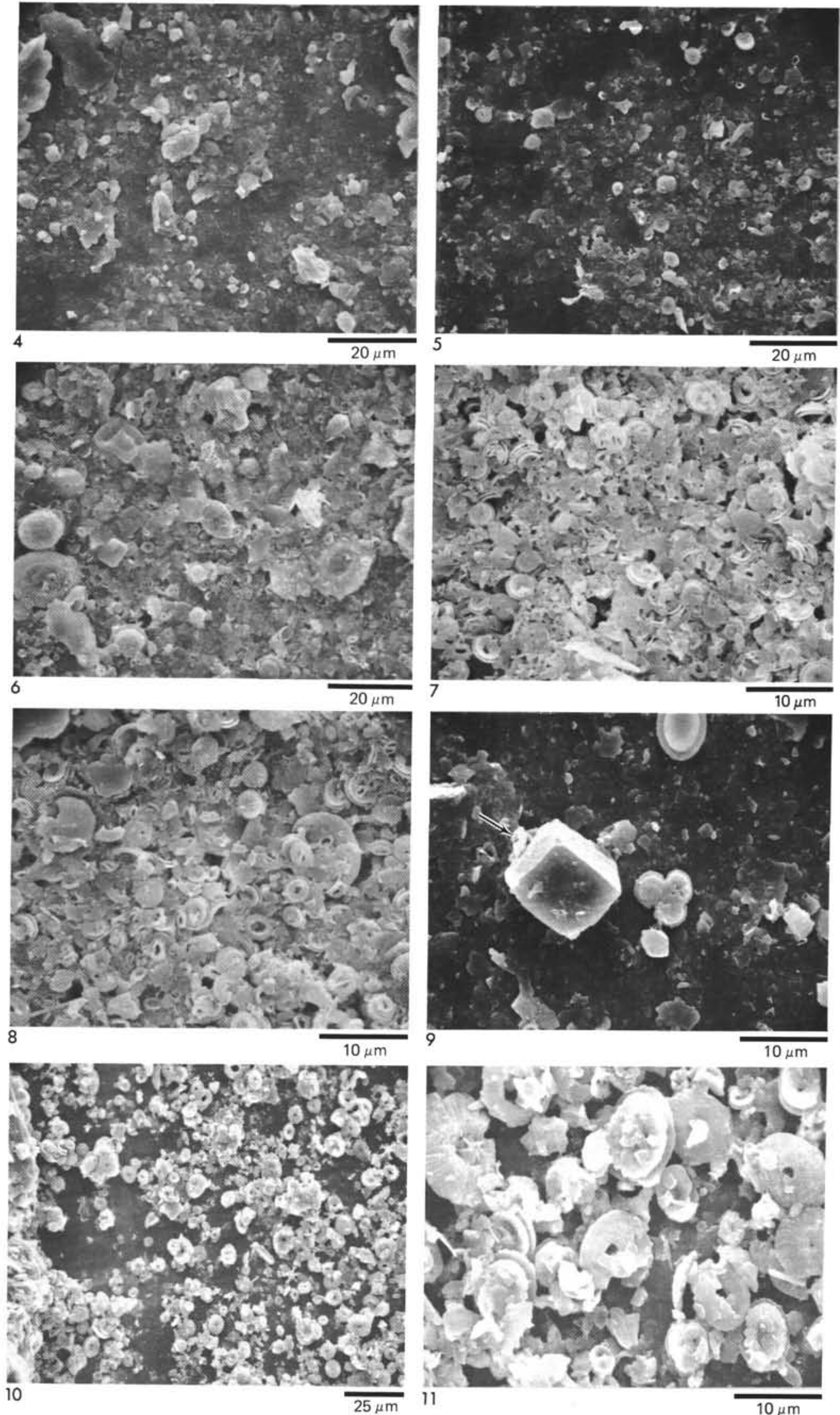


\section{PLATE 2}

Scanning electron microscope photographs of selected lower Cenozoic and Upper Cretaceous sediment types at Site 398; also, photographs of split cores with location of samples and schematic representation of lithologic sections.

Figure 1 Slump deposits, displaying original (thin wavy and parallel laminated) bedding, interbedded in the same core with in-situ pelagic and turbiditic deposits.

Figures 2-4 Selected core sections showing incomplete turbiditic sequences and pelagic deposits of the rhythmic facies association.

Figure 5 Red mudstone and claystone pelagic deposits alternating with incomplete turbiditic sequences.

Figures 6, 7 Slump (6) deposit showing greater abundance and lesser fragmentation in the nannofossil assemblages than the pelagic (7) deposit.

Figures 8, 9 Photographs comparing the fine-grained fraction of the pale brown (9) mudstone type and the diagenetic derivative greenish gray (8) mudstone, which is differentiated by lesser abundance and poorer preservation of the calcareous components.

Figures 10, 11 Pelagic (10) and turbiditic mud (11) deposits showing differences of abundance and preservation in the nannofossil assemblages as a result of dissolution.

Figures 12,13 Red (12) and greenish (13) mudstones deposited below calcite compensation depth. Symbols as for Table 2 and Figure 9. 
PLATE 2

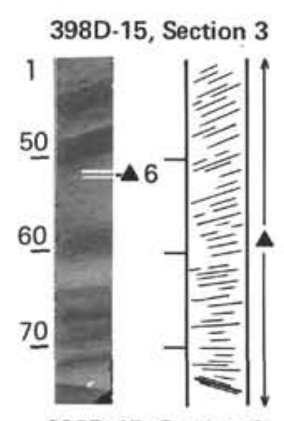

398D-15, Section 6

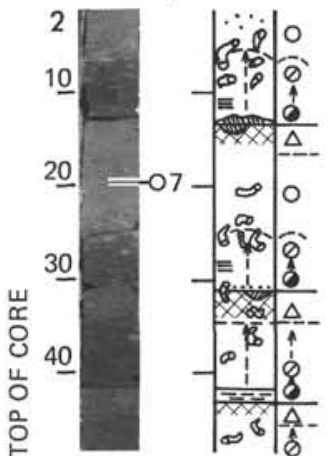

398D-19, Section 3

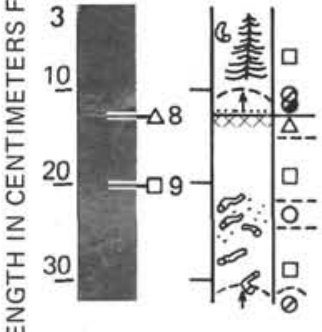

Щ

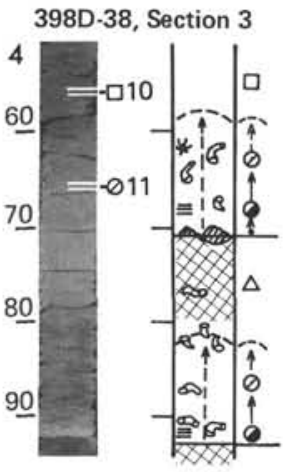

398D-55, Section 2

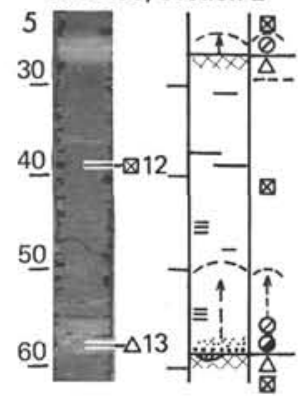

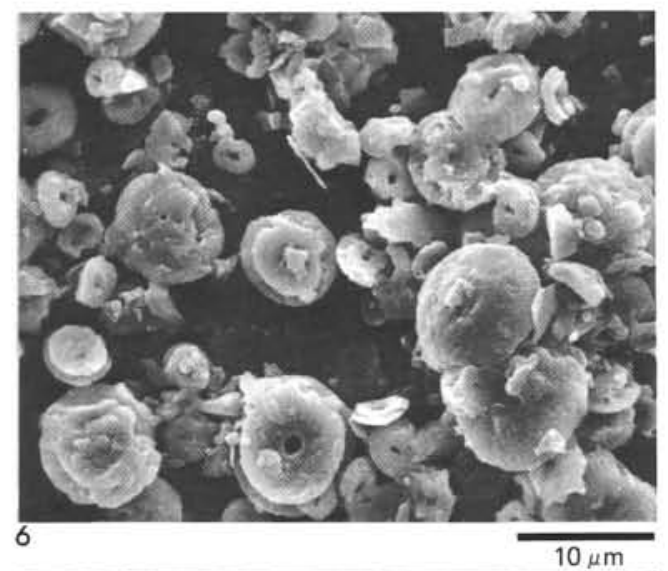
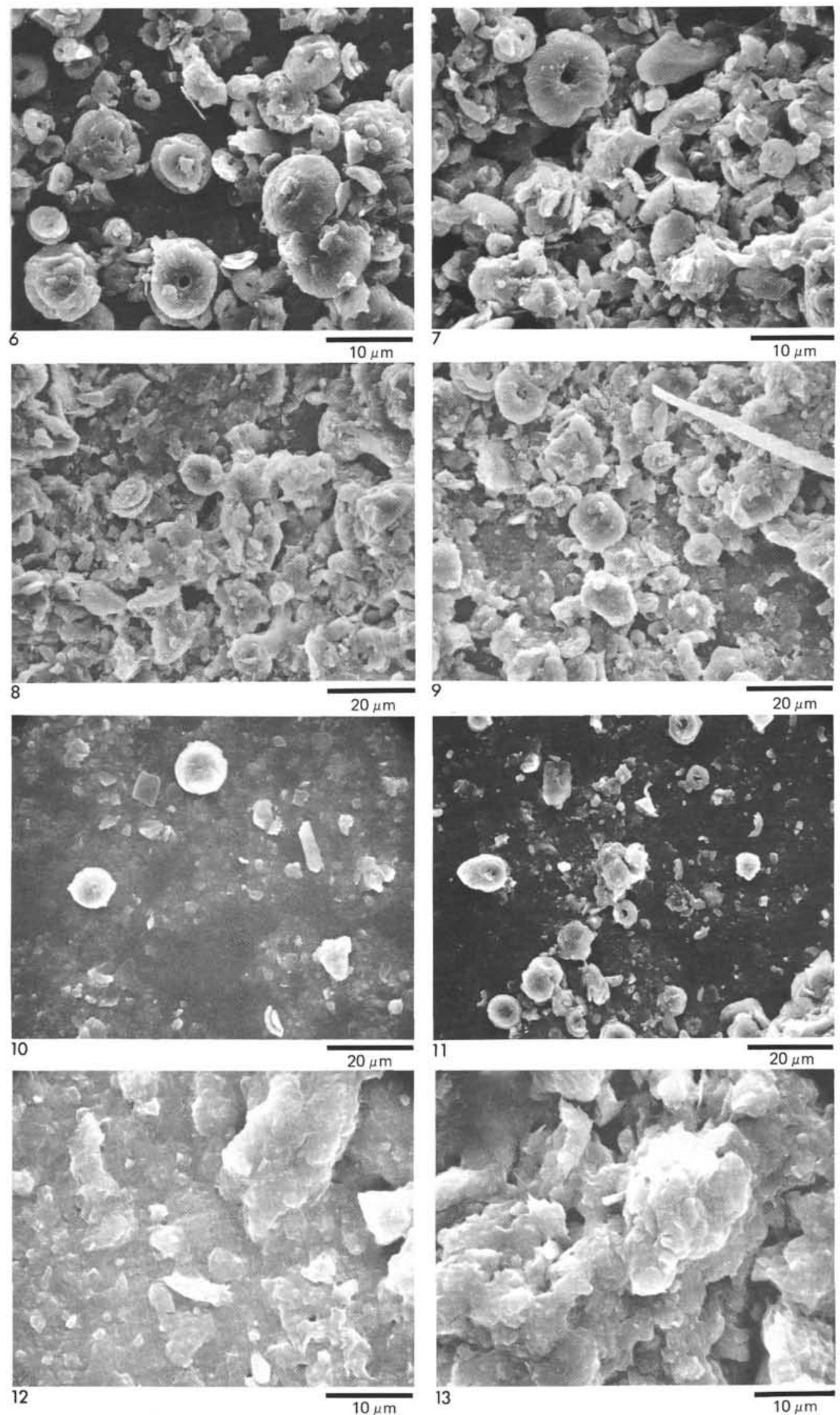
APPENDIX A

Sample Listing: Site 398, Andrés Maldonado

\begin{tabular}{|c|c|c|c|c|c|}
\hline Code & Core & Section & Depth $(\mathrm{cm})$ & & diment Type \\
\hline 130 & 2 & 1 & $63-65$ & 2 & Table 1 \\
\hline 131 & 2 & 2 & $81-83$ & 2 & \\
\hline 132 & 2 & 2 & $128-130$ & 3 & \\
\hline 37 & 2 & 3 & $41-43$ & 3 & \\
\hline 38 & 2 & 3 & $44-46$ & 5 & \\
\hline 39 & 2 & 3 & $47-49$ & 6 & \\
\hline 40 & 2 & 3 & $82-84$ & 1 & \\
\hline 41 & 2 & 3 & $127-129$ & 2 & \\
\hline 42 & 2 & 3 & $\begin{array}{c}145-147 \\
51-52\end{array}$ & 4 & \\
\hline 133 & 2 & 4 & $51-53$ & 2 & \\
\hline 134 & 2 & 4 & $118-120$ & 3 & \\
\hline 135 & 2 & 6 & $16-18$ & 2 & \\
\hline 43 & 3 & 4 & $95-97$ & 2 & \\
\hline 44 & 4 & 4 & $76-80$ & 1 & \\
\hline 45 & 4 & 4 & $96-99$ & 4 & \\
\hline 46 & 4 & 4 & $126-129$ & 3 & \\
\hline 154 & A 1 & 3 & $64-66$ & 5 & \\
\hline 47 & A1 & 3 & $97-99$ & 5 & \\
\hline 48 & A1 & 3 & $134-136$ & 2 & \\
\hline 49 & A 1 & 4 & $19-21$ & 5 & \\
\hline 50 & A1 & 5 & $63-65$ & 1 & \\
\hline 136 & B1 & 2 & $61-63$ & 1 & \\
\hline 137 & B1 & 2 & $67-71$ & 2 & \\
\hline 138 & B1 & 6 & $33-35$ & 1 & \\
\hline 139 & D2 & 1 & $63-67$ & 5 & \\
\hline 51 & D2 & 2 & $25-29$ & 5 & \\
\hline 52 & D2 & 2 & $34-36$ & 3 & \\
\hline 53 & D2 & 2 & $50-54$ & 1 & \\
\hline 54 & D4 & 4 & $36-40$ & 7 & \\
\hline 55 & D4 & 6 & $76-80$ & 5 & \\
\hline 56 & D4 & 6 & $94-98$ & 1 & \\
\hline 140 & D5 & 4 & $90-91$ & 7 & \\
\hline 141 & D5 & 5 & $64-66$ & 1 & \\
\hline 57 & D8 & 1 & $18-19$ & 2 & \\
\hline 58 & D8 & 2 & $18-20$ & $2 / 7$ & \\
\hline 153 & D8 & 2 & $23-27$ & 7 & \\
\hline 59 & D8 & 6 & $7-10$ & 6 & \\
\hline
\end{tabular}

APPENDIX A - Continued

\begin{tabular}{|c|c|c|c|c|c|}
\hline Code & Core & Section & Depth $(\mathrm{cm})$ & & diment Type \\
\hline 1 & D12 & 2 & 4-6 & & Table 2 \\
\hline 2 & D12 & 2 & $51-52$ & 6 & \\
\hline 3 & D12 & 2 & $138-141$ & 3 & \\
\hline 4 & D13 & 2 & $\begin{array}{l}44-45 \\
55-57\end{array}$ & 4 & \\
\hline 5 & D13 & 2 & $55-57$ & 5 & \\
\hline 6 & D13 & 4 & $54-56$ & 3 & \\
\hline 7 & D13 & 5 & $46-48$ & 7 & \\
\hline 155 & D15 & 1 & $11-13$ & 5 & \\
\hline $\begin{array}{l}8 \\
9\end{array}$ & $\begin{array}{l}\text { D15 } \\
\text { D15 }\end{array}$ & $\begin{array}{l}3 \\
6\end{array}$ & $\begin{array}{l}51-53 \\
18-21\end{array}$ & $\begin{array}{l}8 \\
3\end{array}$ & \\
\hline 10 & D15 & 6 & $40-42$ & 6 & \\
\hline $\begin{array}{l}10 \\
11\end{array}$ & $\begin{array}{l}\text { D15 } \\
\text { D15 }\end{array}$ & 6 & $\begin{array}{l}40-42 \\
65-66\end{array}$ & 7 & \\
\hline 12 & D19 & 1 & $33-35$ & 4 & \\
\hline 13 & D19 & 1 & $47-49$ & 3 & \\
\hline 14 & D19 & 1 & $58-60$ & 5 & \\
\hline 15 & D19 & 3 & $10-12$ & 6 & \\
\hline 16 & D19 & 3 & $12-14$ & 1 & \\
\hline 17 & D19 & 3 & $20-22$ & 4 & \\
\hline 18 & D20 & 3 & $135-137$ & 7 & \\
\hline 19 & D24 & 6 & $89-91$ & 7 & \\
\hline 20 & D30 & 1 & $46-48$ & 1 & \\
\hline 21 & D30 & 1 & $51-53$ & 4 & \\
\hline 22 & D30 & 1 & $57-59$ & 6 & \\
\hline 23 & D31 & 2 & $119-121$ & 6 & \\
\hline 24 & D32 & 3 & $119-121$ & 7 & \\
\hline 25 & D32 & 4 & $22-24$ & 2 & \\
\hline 26 & D38 & 1 & $134-136$ & 1 & \\
\hline 27 & D38 & 2 & $126-128$ & 7 & \\
\hline $\begin{array}{l}28 \\
29\end{array}$ & $\begin{array}{l}\text { D38 } \\
\text { D38 }\end{array}$ & $\begin{array}{l}3 \\
3\end{array}$ & $\begin{array}{l}55-57 \\
66-68\end{array}$ & $\begin{array}{l}4 \\
5\end{array}$ & \\
\hline & & 5 & $16-18$ & 2 & \\
\hline $\begin{array}{l}30 \\
31\end{array}$ & D40 & 2 & $86-88$ & 4 & \\
\hline 32 & D40 & 2 & $95-97$ & 5 & \\
\hline 33 & D40 & 2 & $98-100$ & 7 & \\
\hline 34 & D40 & 6 & $52-53$ & 4 & \\
\hline 35 & D41 & 1 & $22-24$ & 4 & \\
\hline 36 & D41 & 5 & $44-46$ & 5 & \\
\hline 60 & D45 & 6 & $80-82$ & 4 & \\
\hline 61 & D45 & 6 & $115-117$ & 5 & \\
\hline 62 & D45 & 6 & $119-121$ & 5 & \\
\hline 63 & D52 & 2 & $95-97$ & 2 & \\
\hline 64 & D55 & 2 & $38-40$ & 2 & \\
\hline 65 & D55 & 2 & $57-58$ & 1 & \\
\hline 66 & D56 & 1 & $10-12$ & 2 & \\
\hline
\end{tabular}

- Note: Sediment types: See Tables 1 and 2. 
APPENDIX B

Sediment Composition and Texture

\begin{tabular}{|c|c|c|c|c|c|c|c|c|c|c|c|c|c|c|c|}
\hline \multirow{3}{*}{$\begin{array}{c}\text { Sample } \\
\text { Code }\end{array}$} & \multicolumn{9}{|c|}{ Texture } & \multirow{2}{*}{\multicolumn{2}{|c|}{ Nannoplankton }} & \multirow{2}{*}{\multicolumn{3}{|c|}{ Sand Fraction }} & \multirow{3}{*}{$\begin{array}{c}\mathrm{CaCO}_{3} \\
(\%)\end{array}$} \\
\hline & \multicolumn{3}{|c|}{$\%$} & \multicolumn{2}{|c|}{$\mu \mathrm{m}$} & \multicolumn{4}{|c|}{$\phi$} & & & & & & \\
\hline & Sand & Silt & Clay & $\mathrm{C}$ & $\bar{M}$ & $\operatorname{Md} \varphi$ & $\mathrm{M}_{\varphi}$ & $\sigma \varphi$ & $\alpha \varphi$ & Abund. & Preserv. & $\mathrm{F} / \mathrm{W}$ & $\mathrm{B} / \mathrm{P}$ & $\mathrm{T} / \mathrm{B}$ & \\
\hline 130 & 5.6 & 30.7 & 63.7 & 146 & 2 & 8.7 & 8.89 & 2.53 & 0.04 & \multicolumn{2}{|c|}{$\mathrm{N} / \mathrm{D}$} & 0.60 & 0.02 & 0.08 & 41.3 \\
\hline 131 & 8.3 & 31.9 & 59.8 & 299 & 2 & 9.1 & 8.88 & 3.28 & -0.08 & \multicolumn{2}{|c|}{$N / D$} & 0.21 & 0.01 & 0.02 & 43.8 \\
\hline 132 & 1.8 & 30.2 & 68.0 & 68 & 1 & 9.3 & 9.43 & 2.43 & 0.01 & \multicolumn{2}{|c|}{$\mathrm{N} / \mathrm{D}$} & 1.16 & 0.05 & 0.05 & 16.5 \\
\hline 37 & 3.7 & 34.1 & 66.2 & 98 & 2 & 9.0 & 12.06 & 6.00 & 0.54 & 7 & -2 & 0.69 & 0.02 & 0.09 & 27.9 \\
\hline 38 & 2.4 & 40.3 & 57.3 & 92 & 3 & 8.0 & 10.03 & 4.17 & 0.41 & 21 & -1 & 0.55 & 0.09 & 0.28 & 27.9 \\
\hline 39 & 11.1 & 62.0 & 26.9 & 130 & 11 & 6.4 & 0.16 & 3.22 & 0.53 & 29 & -1 & 0.60 & 0.05 & 12.97 & 8.2 \\
\hline 40 & 5.7 & 32.9 & 61.4 & 220 & 2 & 8.7 & 8.47 & 2.32 & -0.10 & 160 & 0 & 0.40 & 0.01 & 0.04 & 70.7 \\
\hline 41 & 7.4 & 22.1 & 70.5 & 157 & 2 & 8.9 & 9.26 & 2.78 & 0.18 & 145 & 0 & 0.32 & 0.01 & 0.00 & 60.9 \\
\hline 42 & 4.5 & 53.6 & 41.9 & 80 & 5 & 7.6 & 7.71 & 2.01 & 0.03 & 4 & -1 & 6.65 & 0.06 & 3.08 & 13.9 \\
\hline 133 & 4.5 & 24.4 & 71.1 & 210 & 2 & 9.0 & 8.86 & 2.27 & -0.09 & \multicolumn{2}{|c|}{ N/D } & 0.69 & 0.04 & 0.03 & 55.4 \\
\hline 134 & 3.4 & 40.4 & 56.2 & 94 & 3 & 8.6 & 8.31 & 2.77 & -0.11 & & & 2.40 & 0.04 & 1.61 & 22.3 \\
\hline 135 & 3.7 & 16.9 & 79.4 & 125 & 1 & 9.3 & 9.58 & 1.95 & 0.09 & & & 0.56 & 0.01 & 0.03 & 66.1 \\
\hline 43 & 3.5 & 41.5 & 55.0 & 120 & 3 & 8.4 & 8.88 & 2.85 & 0.14 & 150 & 0 & 1.15 & 0.04 & 0.09 & 55.9 \\
\hline 44 & 4.9 & 30.7 & 64.4 & 275 & 2 & 8.7 & 8.68 & 2.07 & -0.02 & 125 & -2 & 0.47 & 0.00 & 0.01 & 69.1 \\
\hline 45 & 0.3 & 24.5 & 75.2 & 35 & 1 & 9.4 & 10.12 & 2.76 & 0.23 & 1 & -3 & 1.87 & 0.11 & 1.35 & 4.9 \\
\hline 46 & 1.5 & 32.3 & 66.2 & 89 & 2 & 8.6 & 9.21 & 2.13 & 0.24 & 22 & -2 & 4.24 & 0.18 & 0.05 & 49.3 \\
\hline 154 & 1.3 & 28.7 & 70.0 & 74 & 0.9 & 9.9 & 11.12 & 4.28 & 0.26 & $\mathrm{~N}$ & & 0.32 & 0.04 & 0.10 & 20.4 \\
\hline 47 & 3.5 & 33.4 & 63.1 & 251 & 3 & 8.5 & 8.78 & 2.00 & 0.09 & 28 & -2 & 0.82 & 0.02 & 0.01 & 55.9 \\
\hline 48 & 0.8 & 36.1 & 63.1 & 40 & 2 & 8.7 & 8.58 & 1.73 & -0.11 & 37 & -1 & 0.25 & 0.03 & 0.22 & 65.8 \\
\hline 49 & 0.9 & 44.8 & 54.3 & 56 & 3 & 8.3 & 8.29 & 1.68 & -0.04 & 27 & -2 & 1.51 & 0.08 & 0.13 & 42.7 \\
\hline 50 & 4.1 & 27.7 & 68.2 & 93 & 2 & 9.0 & 9.21 & 2.05 & 0.10 & 58 & -2 & 2.10 & 0.06 & 0.02 & 70.7 \\
\hline 136 & 6.1 & 26.1 & 67.8 & 108 & 2 & 8.9 & 8.60 & 2.10 & -0.16 & $\mathrm{~N}$ & & 0.45 & 0.00 & 0.01 & 76.2 \\
\hline 137 & 4.4 & 22.5 & 73.1 & 86 & 1 & 9.4 & 9.07 & 1.87 & -0.19 & $\mathrm{~N}$ & & 2.40 & 0.02 & 0.01 & 70.5 \\
\hline 138 & 2.4 & 37.5 & 60.1 & 95 & 3 & 8.4 & 8.56 & 2.06 & 0.03 & $\mathrm{~N}$ & & 1.53 & 0.04 & 0.04 & 78.7 \\
\hline 139 & 1.5 & 31.7 & 66.8 & 82 & 2 & 9.2 & 8.77 & 2.03 & -0.21 & $\mathrm{~N}$ & & 4.93 & 0.16 & 0.53 & 22.9 \\
\hline 51 & 1.1 & 33.2 & 65.7 & 68 & 2 & 8.7 & 8.85 & 1.59 & 0.09 & 23 & -1 & 0.27 & 0.08 & 0.17 & 51.0 \\
\hline 52 & 2.4 & 33.4 & 64.2 & 98 & 2 & 8.7 & 8.98 & 1.76 & 0.13 & 21 & -1 & 2.46 & 0.05 & 0.11 & 48.5 \\
\hline 53 & 6.6 & 23.6 & 69.8 & 98 & 2 & 9.0 & 9.04 & 2.19 & 0.00 & 78 & -1 & 0.31 & 0.03 & 0.00 & 74.0 \\
\hline 54 & 0 & 38.4 & 61.6 & 38 & 2 & 8.6 & 8.80 & 1.42 & 0.09 & 28 & 0 & 10.40 & 0.28 & 0.10 & 79.8 \\
\hline 55 & 0 & 38.6 & 61.4 & 34 & 3 & 8.3 & 9.07 & 1.70 & 0.41 & 35 & -2 & 3.29 & 0.14 & 0.47 & 70.7 \\
\hline 56 & 0 & 45.4 & 54.6 & 37 & 4 & 8.0 & 8.51 & 1.15 & 0.37 & 47 & 0 & 5.26 & 0.10 & 0.05 & 85.5 \\
\hline 140 & 38.5 & 46.3 & 15.2 & 88 & 43 & 4.5 & 5.77 & 2.06 & 0.59 & $\mathrm{~N}$ & & 7.50 & 0.00 & 3.43 & 46.7 \\
\hline 141 & 3.4 & 41.2 & 55.4 & 120 & 3 & 8.1 & 8.30 & 2.06 & 0.05 & $\mathrm{~N}$ & & 9.14 & 0.07 & 0.93 & 83.6 \\
\hline 57 & 3.2 & 47.8 & 49.0 & 83 & 4 & 7.9 & 8.34 & 2.29 & 0.19 & 18 & -2 & 8.56 & 0.11 & 0.08 & 60.0 \\
\hline 58 & 7.0 & 46.3 & 46.7 & 88 & 5 & 7.7 & 7.75 & 2.24 & -0.005 & 16 & -2 & 3.19 & 0.03 & 0.03 & 70.7 \\
\hline 153 & 4.2 & 39.9 & 55.9 & 89 & 4 & 8.1 & 8.68 & 2.15 & 0.25 & $\mathrm{~N}$ & & 0.96 & 0.21 & 0.74 & 63.9 \\
\hline 59 & 5.8 & 51.2 & 43.0 & 80 & 5 & 7.6 & 8.52 & 3.32 & 0.27 & 12 & -2 & 0.39 & 0.04 & 0.52 & 39.5 \\
\hline 1 & 3.8 & 61.6 & 34.6 & 75 & 8 & 6.8 & 7.12 & 1.82 & 0.13 & 3 & -2 & 0.36 & 0.09 & 1.12 & 13.9 \\
\hline 2 & 13.6 & 68.9 & 17.5 & 135 & 7 & 7.0 & 0.08 & 1.95 & -0.50 & 10 & -2 & 0.71 & 0.14 & 2.28 & 22.9 \\
\hline 3 & 1.2 & 45.6 & 53.2 & 68 & 4 & 8.0 & 7.99 & 1.36 & -0.04 & 35 & -1 & 2.13 & 0.13 & 0.94 & 65.5 \\
\hline 4 & 0.1 & 48.1 & 51.8 & 40 & 4 & 8.0 & 8.67 & 2.14 & 0.31 & 32 & -2 & 6.48 & 0.24 & 0.54 & 55.7 \\
\hline 5 & 0.9 & 43.3 & 55.8 & 57 & 3 & 8.1 & 8.45 & 1.75 & 0.16 & 3 & -3 & 7.67 & 0.67 & 1.19 & 29.5 \\
\hline 6 & 0 & 43.5 & 56.5 & 43 & 3 & 8.3 & 6.54 & 0.48 & -3.62 & 17 & -2 & 7.79 & 0.32 & 0.59 & 68.8 \\
\hline 7 & 12.7 & 48.4 & 38.9 & 94 & 6 & 7.3 & 6.90 & 2.61 & -0.15 & 6 & -1 & 11.80 & 0.58 & 0.53 & 22.9 \\
\hline 155 & 0.9 & 34.8 & 64.3 & 58 & 3 & 8.6 & 8.65 & 1.93 & 0.01 & $\mathrm{~N}$ & & 3.21 & 0.55 & 0.40 & 37.7 \\
\hline 8 & 1.3 & 53.3 & 45.4 & 71 & 4 & 7.8 & 8.02 & 1.36 & 0.15 & 28 & -2 & 1.75 & 0.07 & 0.54 & 72.1 \\
\hline 9 & 0.7 & 41.7 & 57.6 & 38 & 3 & 8.1 & 8.33 & 1.46 & 0.09 & 14 & -2 & 17.00 & 0.00 & 0.71 & 63.9 \\
\hline 10 & 7.0 & 52.0 & 41.0 & 88 & 6 & 7.3 & 7.27 & 2.48 & -0.01 & 3 & -3 & 5.81 & 0.94 & 0.58 & 26.2 \\
\hline 11 & 49.6 & 28.8 & 21.6 & 159 & 56 & 4.1 & 5.82 & 2.76 & 0.60 & 3 & -1 & 34.7 & 0.14 & 0.80 & 54.0 \\
\hline 12 & 1.0 & 37.0 & 62.0 & 57 & 3 & 8.5 & 9.21 & 2.16 & 0.31 & 5 & -3 & 0.00 & 6.00 & 4.77 & 47.5 \\
\hline 13 & 0.7 & 44.0 & 55.3 & 39 & 4 & 8.1 & 8.22 & 1.75 & 0.07 & 17 & -2 & - & - & 8.02 & 54.0 \\
\hline 14 & 1.6 & 45.9 & 52.5 & 72 & 4 & 8.0 & 8.19 & 2.29 & 0.06 & 6 & -3 & 2.00 & 1.50 & 8.81 & 31.1 \\
\hline 15 & 5.4 & 50.5 & 44.1 & 83 & 5 & 7.5 & 7.68 & 2.51 & 0.04 & 4 & -2 & 0.00 & 1.00 & 5.76 & 19.6 \\
\hline 16 & 1.3 & 37.8 & 50.9 & 76 & 4 & 8.0 & 8.48 & 2.44 & 0.19 & 4 & -3 & - & - & 10.8 & 21.3 \\
\hline 17 & 1.0 & 43.6 & 55.4 & 63 & 3 & 8.1 & 8.53 & 2.15 & 0.17 & 4 & -3 & 0.33 & 0.17 & 3.39 & 41.8 \\
\hline
\end{tabular}


APPENDIX B - Continued

\begin{tabular}{|c|c|c|c|c|c|c|c|c|c|c|c|c|c|c|c|}
\hline \multirow{3}{*}{$\begin{array}{c}\text { Sample } \\
\text { Code }\end{array}$} & \multicolumn{9}{|c|}{ Texture } & \multirow{2}{*}{\multicolumn{2}{|c|}{ Nannoplankton }} & \multirow{2}{*}{\multicolumn{3}{|c|}{ Sand Fraction }} & \multirow{3}{*}{$\begin{array}{c}\mathrm{CaCO}_{3} \\
(\%)\end{array}$} \\
\hline & \multicolumn{3}{|c|}{$\%$} & \multicolumn{2}{|c|}{$\mu \mathrm{m}$} & \multicolumn{4}{|c|}{$\phi$} & & & & & & \\
\hline & Sand & Silt & $\overline{\text { Clay }}$ & $\bar{C}$ & $\bar{M}$ & $\overline{M d} \varphi$ & $\mathrm{M \varphi}$ & $\sigma \varphi$ & $\overline{\alpha \varphi}$ & Abund. & $\overline{\text { Preserv. }}$ & $\bar{F} / W$ & $\mathrm{~B} / \mathrm{P}$ & $\overline{T / B}$ & \\
\hline 18 & 38.4 & 25.2 & 36.4 & 220 & 21 & 5.5 & 5.49 & 4.14 & -0.01 & 4 & -3 & 9.2 & 0.25 & 1.06 & 42.6 \\
\hline 19 & 54.2 & 44.0 & 1.8 & 193 & 58 & 4.1 & 4.09 & 1.38 & -0.003 & 8 & -3 & 1.23 & 0.07 & 0.28 & 42.6 \\
\hline 20 & 2.0 & 25.5 & 72.5 & 100 & 1 & 9.8 & 11.50 & 4.19 & 0.40 & 1 & -4 & 18.9 & 0.00 & 0.26 & 16.3 \\
\hline 21 & 1.0 & 32.5 & 66.5 & 63 & 2 & 8.6 & 11.54 & 4.95 & 0.57 & 4 & -4 & 86.3 & 0.67 & 0.77 & 24.5 \\
\hline 22 & 2.2 & 41.0 & 56.8 & 85 & 3 & 8.3 & 8.70 & 2.80 & 0.12 & 0 & -4 & $\infty$ & - & 28.4 & 22.1 \\
\hline 23 & 4.4 & 46.0 & 49.6 & 84 & 4 & 7.9 & 8.27 & 3.03 & 0.11 & 1 & -4 & $\infty$ & - & 19.2 & 18.0 \\
\hline 24 & 64.1 & 17.8 & 18.1 & 209 & 165 & 2.6 & 5.32 & 2.98 & 0.91 & 2 & -3 & 2.35 & 0.05 & 0.13 & 68.8 \\
\hline 25 & 0.5 & 28.7 & 70.8 & 38 & 0.2 & 12.0 & 16.40 & 10.40 & 0.42 & 1 & -4 & 0.00 & 0.50 & 25.5 & 14.7 \\
\hline 26 & 0 & 14.9 & 85.1 & 37 & 0.4 & 11.2 & 13.15 & 5.11 & 0.36 & 2 & -4 & 6.00 & 1.50 & 10.9 & 21.3 \\
\hline 27 & 27.7 & 25.8 & 46.5 & 128 & 5 & 7.5 & 8.20 & 4.70 & 0.13 & 3 & -3 & 16.2 & 0.07 & 1.00 & 26.2 \\
\hline 28 & 0 & 15.7 & 84.3 & 34 & 1 & 10.6 & 11.02 & 2.99 & 0.13 & 2 & -4 & 2.75 & 1.25 & 4.09 & 14.7 \\
\hline 29 & 0 & 26.7 & 73.3 & 33 & 1 & 9.3 & 11.10 & 3.74 & 0.45 & 6 & -3 & 2.08 & 0.33 & 2.72 & 39.3 \\
\hline 30 & 0 & 23.3 & 76.7 & 34 & 0.4 & 11.2 & 12.83 & 5.46 & 0.29 & 0 & -5 & - & - & 2.72 & 6.5 \\
\hline 31 & 0 & 23.6 & 76.4 & 37 & 1 & 9.5 & 12.77 & 6.00 & 0.53 & 3 & -4 & 0.75 & 0.17 & 5.39 & 29.6 \\
\hline 32 & 1.7 & 27.0 & 71.3 & 94 & 2 & 9.1 & 10.71 & 3.43 & 0.44 & 7 & -3 & 1.60 & 0.12 & 0.29 & 52.6 \\
\hline 33 & 13.2 & 37.7 & 49.1 & 115 & 4 & 7.9 & 7.72 & 3.25 & -0.05 & 19 & -2 & 1.39 & 0.07 & 0.26 & 62.5 \\
\hline 34 & 0 & 18.1 & 81.9 & 32 & 0.4 & 11.2 & 13.11 & 5.32 & 0.35 & 3 & -4 & 1.69 & 0.07 & 2.84 & 31.2 \\
\hline 35 & 5.7 & 31.7 & 62.6 & 239 & 1 & 9.7 & 9.99 & 4.46 & 0.05 & 6 & -4 & 0.58 & 0.20 & 0.01 & 37.8 \\
\hline 36 & 0 & 41.3 & 58.7 & 36 & 3 & 8.2 & 8.59 & 1.69 & 0.19 & 13 & -2 & 1.47 & 0.18 & 1.57 & 74.0 \\
\hline 60 & 0 & 21.6 & 78.4 & 33 & 1 & 9.4 & 9.74 & 2.10 & 0.12 & 2 & -4 & 0.45 & 2.00 & 5.16 & 27.9 \\
\hline 61 & 0 & 22.8 & 77.2 & 33 & 1 & 9.5 & 9.88 & 2.48 & 0.14 & 2 & -3 & 0.76 & 0.94 & 5.18 & 37.0 \\
\hline 62 & 0.6 & 32.3 & 67.1 & 45 & 2 & 8.6 & 8.91 & 2.42 & 0.09 & 4 & -3 & 2.00 & 0.67 & 21.8 & 36.2 \\
\hline 63 & 0 & 22.3 & 77.7 & 36 & 0.1 & 12.7 & 15.85 & 9.15 & 0.34 & 0 & -5 & 2.77 & 0.23 & 0.65 & 2.4 \\
\hline 64 & 1.1 & 21.1 & 77.8 & 65 & 0.1 & 13.1 & 17.40 & 10.4 & 0.41 & 0 & -5 & 5.75 & 0.25 & 4.49 & 1.6 \\
\hline 65 & 2.6 & 19.4 & 78.0 & 82 & 0.02 & 15.5 & 20.5 & 13.8 & 0.36 & 0 & -5 & - & - & 9.13 & 1.6 \\
\hline 66 & 0 & 33.6 & 66.4 & 38 & 1 & 9.5 & 11.28 & 4.65 & 0.37 & 0 & -5 & - & - & 2.12 & 3.2 \\
\hline
\end{tabular}


APPENDIX C

Composition of the Sand Fraction ( $>63 \mu \mathrm{m})$

\begin{tabular}{|c|c|c|c|c|c|c|c|c|c|c|c|}
\hline \multirow[b]{2}{*}{ Code } & \multicolumn{6}{|c|}{ \%o Biogenic } & & & Terrigen & & \\
\hline & F. Plankt. & F. Bent. & F.P. Frag. & Shells & Radiol. & Others & \& Pyrite & Mica & Miner. & Others & $\mathrm{N}^{\circ}$ Grains \\
\hline 130 & 56.1 & 0.9 & $33.5^{\circ}$ & 0.2 & - & 0.2 & 2.2 & 0.9 & - & 6.0 & 465 \\
\hline 131 & 80.5 & 0.7 & 16.6 & 0.2 & - & - & 0.2 & 0.7 & 0.5 & 0.5 & 410 \\
\hline 132 & 42.5 & 2.1 & 49.4 & - & - & - & 1.3 & 2.9 & 1.1 & 0.8 & 380 \\
\hline 37 & 52.5 & 1.2 & 36.5 & - & - & 0.2 & 1.2 & 4.4 & 1.9 & 2.1 & 482 \\
\hline 38 & 46.6 & 4.2 & 25.8 & 1.0 & 0.2 & - & 0.2 & 8.5 & 10.1 & 3.4 & 496 \\
\hline 39 & 4.3 & 1.2 & 2.6 & - & - & 0.2 & - & 8.8 & 83.6 & 0.2 & 463 \\
\hline 40 & 68.4 & 0.4 & 27.3 & - & - & - & 0.2 & 0.9 & 2.8 & - & 469 \\
\hline 41 & 75.3 & 0.4 & 23.9 & - & - & - & 0.2 & 0.2 & - & - & 503 \\
\hline 42 & 3.1 & 0.2 & 20.8 & - & - & - & 1.5 & 9.8 & 16.2 & 48.4 & 543 \\
\hline 133 & 56.0 & 2.3 & 38.8 & 0.4 & - & - & - & 0.4 & 0.2 & 1.9 & 484 \\
\hline 134 & 11.0 & 0.4 & 26.3 & - & 0.2 & 0.2 & 0.6 & 5.0 & 10.1 & 46.2 & 483 \\
\hline 135 & 61.0 & 0.9 & 34.2 & - & - & 0.4 & 0.6 & 1.3 & 1.5 & - & 461 \\
\hline 43 & 41.1 & 1.4 & 47.4 & - & 0.2 & - & 2.2 & 3.5 & 4.3 & - & 492 \\
\hline 44 & 67.1 & 0.2 & 31.4 & - & - & - & - & 0.6 & 0.8 & - & 510 \\
\hline 45 & 9.4 & 1.0 & 17.6 & - & - & 2.1 & 29.3 & 17.4 & 23.0 & 0.2 & 478 \\
\hline 46 & 17.4 & 3.2 & 73.9 & 0.2 & - & 0.4 & 0.4 & 2.1 & 1.0 & 0.4 & 472 \\
\hline 154 & 284.0 & 10.0 & 90.0 & 1.0 & - & 2.0 & 74.0 & 1.0 & 35.0 & 2.0 & 499 \\
\hline 47 & 53.6 & 1.1 & 43.6 & - & - & 0.6 & 0.2 & 0.4 & 0.4 & - & 472 \\
\hline 48 & 61.5 & 1.8 & 15.2 & 1.0 & - & - & 3.1 & 4.1 & 13.3 & - & 488 \\
\hline 49 & 32.0 & 2.6 & 48.5 & - & 0.2 & 0.4 & 5.6 & 7.4 & 3.0 & 0.2 & 462 \\
\hline 50 & 30.7 & 1.7 & 65.0 & 0.4 & - & 0.2 & 0.6 & 0.6 & 0.6 & 0.4 & 525 \\
\hline 136 & 68.3 & 0.2 & 30.4 & 0.2 & - & 0.2 & - & - & 0.4 & 0.2 & 470 \\
\hline 137 & 28.5 & 0.6 & 68.5 & 0.2 & - & 0.2 & 0.6 & 0.4 & 1.0 & - & 499 \\
\hline 138 & 37.3 & 1.4 & 57.0 & 0.2 & - & - & - & 1.1 & 2.7 & 0.3 & 628 \\
\hline 139 & 8.3 & 1.4 & 41.2 & 0.4 & - & - & 21.6 & 18.1 & 8.2 & 0.8 & 515 \\
\hline 51 & 59.3 & 4.5 & 16.2 & 0.9 & - & 1.3 & 3.6 & 4.7 & 9.6 & - & 469 \\
\hline 52 & 25.5 & 1.4 & 62.5 & 0.2 & - & - & 1.0 & 5.7 & 3.3 & 0.5 & 581 \\
\hline 53 & 73.8 & 2.0 & 23.0 & 0.2 & - & 0.4 & 0.4 & - & 0.2 & - & 504 \\
\hline 54 & 7.5 & 2.1 & 78.4 & 0.8 & - & 1.7 & 1.5 & 1.0 & 6.6 & 1.2 & 519 \\
\hline 55 & 14.4 & 2.0 & 47.0 & 2.2 & - & 0.2 & 3.2 & 4.2 & 22.7 & 4.2 & 501 \\
\hline 56 & 14.6 & 1.4 & 76.8 & 1.6 & - & 0.2 & 0.8 & 1.6 & 2.2 & 0.6 & 492 \\
\hline 140 & 0.3 & - & 2.1 & - & - & 19.3 & 3.6 & 9.6 & 26.4 & 38.7 & 698 \\
\hline 141 & 4.4 & 0.3 & 40.1 & - & 0.8 & 5.9 & 0.5 & 2.5 & 1.1 & 44.4 & 639 \\
\hline 57 & 2.0 & 0.2 & 17.0 & 0.2 & 69.5 & 3.8 & - & 4.6 & 1.8 & 0.9 & 453 \\
\hline 58 & 21.2 & 0.6 & 67.6 & 0.6 & 3.3 & 4.1 & - & 1.7 & 1.0 & - & 515 \\
\hline 153 & 78.0 & 16.0 & 75.0 & 2.0 & 11.0 & 13.0 & - & 1.0 & 6.0 & 160.0 & 363 \\
\hline 59 & 17.2 & 0.6 & 6.7 & 0.2 & 19.9 & 21.1 & 0.2 & 24.3 & 9.1 & 0.6 & 493 \\
\hline 1 & 4.5 & 0.4 & 1.6 & - & 2.1 & 38.5 & - & 28.6 & 21.4 & 2.9 & 486 \\
\hline 2 & 1.4 & 0.2 & 1.0 & - & 1.6 & 26.3 & 0.4 & 16.2 & 50.7 & 2.3 & 513 \\
\hline 3 & 3.1 & 0.4 & 6.6 & 0.4 & 5.1 & 36.0 & - & 19.8 & 28.6 & - & 486 \\
\hline 4 & 5.6 & 1.4 & 36.5 & 1.0 & 15.0 & 5.6 & - & 13.8 & 20.2 & 1.0 & 515 \\
\hline 5 & 0.6 & 0.4 & 4.5 & - & 1.4 & 30.8 & - & 29.1 & 24.3 & 1.0 & 515 \\
\hline 6 & 4.0 & 1.3 & 31.3 & 0.4 & 4.0 & 21.8 & - & 10.6 & 24.5 & 2.1 & 473 \\
\hline 7 & 2.6 & 1.5 & 30.3 & - & 1.3 & 29.5 & - & 9.9 & 21.9 & 3.0 & 465 \\
\hline 155 & 29.6 & 16.0 & 93.0 & 8.0 & - & 120.0 & 3.0 & 76.0 & 30.0 & - & 375 \\
\hline 8 & 13.3 & 0.9 & 23.3 & - & 1.2 & 26.1 & - & 29.5 & 5.5 & 0.2 & 563 \\
\hline 9 & 1.3 & - & 22.1 & - & 0.7 & 34.3 & - & 28.4 & 13.0 & 0.2 & 461 \\
\hline 10 & 3.2 & 3.0 & 18.3 & - & 0.6 & 38.1 & - & 26.8 & 10.1 & - & 507 \\
\hline 11 & 1.0 & 0.1 & 34.8 & - & 1.1 & 18.3 & - & 19.8 & 24.4 & 0.4 & 698 \\
\hline 12 & 0.2 & 1.1 & - & 5.5 & 0.2 & 10.3 & - & 27.5 & 54.7 & 0.5 & 561 \\
\hline 13 & - & - & - & 3.2 & - & 5.9 & - & 22.4 & 66.2 & 0.4 & 541 \\
\hline 14 & 0.4 & 0.6 & 0.8 & 2.3 & - & 5.9 & 0.2 & 46.8 & 42.8 & - & 472 \\
\hline 15 & 0.2 & 0.2 & - & - & - & 14.4 & - & 43.7 & 41.5 & - & 568 \\
\hline 16 & - & - & - & - & - & 8.5 & - & 52,4 & 38.9 & 0.2 & 435 \\
\hline 17 & 1.2 & 0.2 & 0.4 & 0.6 & 0.8 & 19.5 & - & 43.3 & 33.9 & - & 492 \\
\hline 18 & 4.3 & 1.1 & 40.0 & 1.1 & 1.3 & 0.7 & - & 3.9 & 47.6 & - & 460 \\
\hline 19 & 30.8 & 2.2 & 38.0 & 0.2 & 4.9 & 2.0 & - & 4.5 & 17.4 & - & 446 \\
\hline 20 & 4.0 & - & 74.8 & 0.4 & - & - & - & 7.9 & 12.0 & - & 481 \\
\hline 21 & 0.6 & 0.4 & 55.0 & 0.4 & - & - & - & 30.8 & 12.5 & 0.2 & 471 \\
\hline 22 & - & - & 3.4 & - & - & - & - & 51.3 & 44.9 & 0.4 & 530 \\
\hline 23 & - & - & 4.6 & - & - & 2.4 & - & 56.5 & 25.4 & 11.1 & 504 \\
\hline 24 & 25.8 & 1.3 & 60.6 & 0.7 & - & 0.2 & - & 0.2 & 2.0 & 8.4 & 454 \\
\hline 25 & 0.4 & 0.2 & - & 2.7 & - & 0.5 & - & 17.6 & 4.5 & 74.1 & 556 \\
\hline 26 & 0.4 & 0.6 & 2.6 & 3.9 & - & 0.9 & 0.2 & 16.4 & 75.0 & - & 464 \\
\hline 27 & 2.9 & 0.2 & 46.8 & - & - & - & - & 0.4 & 49.5 & 0.2 & 485 \\
\hline 28 & 1.0 & 1.3 & 2.8 & 14.5 & - & - & 0.5 & 3.0 & 76.9 & - & 394 \\
\hline 29 & 4.9 & 1.6 & 10.3 & 9.5 & - & 0.4 & 0.2 & 2.3 & 70.4 & 0.4 & 486 \\
\hline 30 & - & - & - & 0.4 & - & - & - & 2.3 & 50.8 & 46.5 & 486 \\
\hline 31 & 4.6 & 0.8 & 3.4 & 6.3 & - & 0.6 & - & 5.2 & 79.0 & 0.2 & 524 \\
\hline 32 & 28.5 & 3.3 & 45.3 & 0.2 & - & - & - & 9.8 & 12.7 & 0.2 & 488 \\
\hline 33 & 32.2 & 2.4 & 44.8 & - & - & - & - & 2.9 & 17.7 & - & 509 \\
\hline 34 & 6.3 & 0.4 & 10.6 & 6.9 & - & 1.9 & - & 4.8 & 69.1 & - & 463 \\
\hline 35 & 55.5 & 11.0 & 32.5 & - & - & - & - & 0.7 & 0.4 & - & 456 \\
\hline 36 & 13.4 & 2.4 & 19.7 & 3.2 & - & 0.2 & - & 32.1 & 21.9 & 7.1 & 462 \\
\hline 60 & 2.3 & 4.6 & 1.1 & 1.9 & 0.4 & 5.9 & 0.4 & 44.7 & 11.8 & 26.9 & 476 \\
\hline 61 & 3.3 & 3.1 & 2.5 & 3.5 & 0.4 & 2.7 & 4.7 & 41.6 & 18.3 & 20.0 & 516 \\
\hline 62 & 0.6 & 0.4 & 1.2 & - & 0.2 & 1.8 & 6.5 & 26.2 & 55.8 & 7.4 & 511 \\
\hline 63 & 5.8 & 1.3 & 16.2 & 30.2 & 1.1 & 3.4 & 4.0 & 3.4 & 18.8 & 15.6 & 377 \\
\hline 64 & 0.8 & 0.2 & 4.5 & 8.3 & 0.6 & 3.0 & 4.7 & 7.5 & 5.7 & 64.7 & 507 \\
\hline 65 & - & - & - & 8.3 & - & 1.6 & 3.1 & 7.3 & 73.8 & 6.0 & 385 \\
\hline 66 & - & - & - & 18.0 & 89.0 & 16.0 & 2.0 & 73.0 & 82.0 & 106.0 & 380 \\
\hline
\end{tabular}

